Nevada

Environmental

Restoration

Project

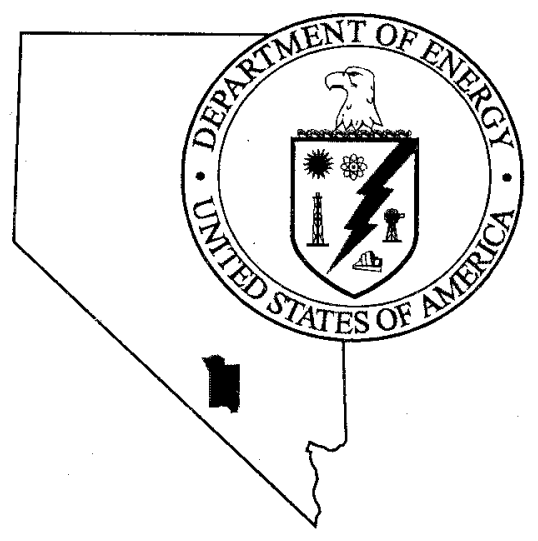

Annual Report

RCRA Post-Closure Monitoring and Inspections for

Corrective Action Unit 91:

Area 3 U-3fi Waste Unit,

Nevada Test Site, Nevada

For the Period

October 1997 - October 1998

Controlled Copy No.

Revision: 0

January 1999

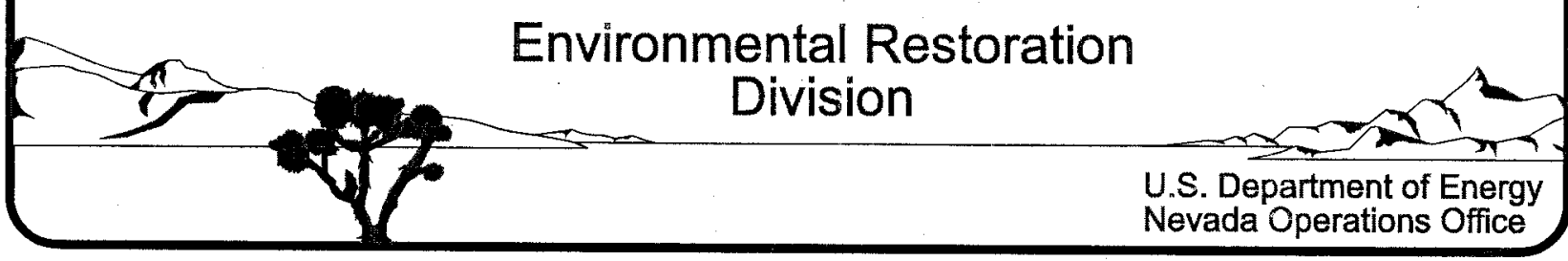


Available to the public from:

U.S. Department of Commerce

National Technical Information Service

5285 Port Royal Road

Springfield, VA 22161-0002

Available electronically at http://www.doe gov/bridge. Available to U.S. Department of Energy and its contractors in paper from:

U.S. Department of Energy

Office of Scientific and Technical Information

P.O. Box 62

Oak Ridge, TN 37831-0062

(423) $576-8401$

Reference herein to any specific commercial product, process, or service by trade name, trademark, manufacturer, or otherwise, does not necessarily constitute or imply its endorsement, recommendation, or favoring by the U.S. Government or any agency thereof or its contractors or subcontractors. 


\section{ANNUAL REPORT \\ RCRA POST-CLOSURE MONITORING \\ AND INSPECTIONS FOR \\ CORRECTIVE ACTION UNIT 91: \\ AREA 3 U-3fi WASTE UNIT, \\ NEVADA TEST SITE, NEVADA}

\section{FOR THE PERIOD \\ OCTOBER 1997 - OCTOBER 1998}

Controlled Copy No.:

Revision: 0

January 1999

Prepared for U.S. Department of Energy

Nevada Operations Office

Under Contract No. DE-AC08-96NV11718 


\section{THIS PAGE INTENTIONALLY LEFT BLANK}




\section{ANNUAL REPORT \\ RCRA POST-CLOSURE MONITORING AND INSPECTIONS FOR CORRECTIVE ACTION UNIT 91: \\ AREA 3 U-3Fi WASTE UNIT, NEVADA TEST SITE, NEVADA} Approved by: Date: $2 / 2 / 99$

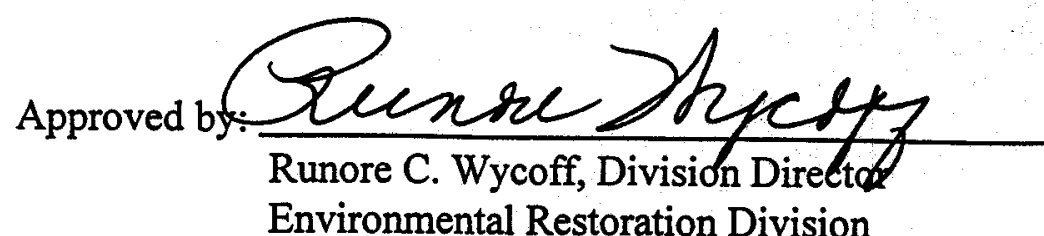
Date: $\frac{2-2-9}{7}$ 
THIS PAGE INTENTIONALLY LEFT BLANK 


\section{TABLE OF CONTENTS}

FIGURES vi

TABLES

ACRONYMS AND ABBREVIATIONS . vi

ABSTRACT vii ABSTRACT

PROJECT SUMMARY PS-1

1.0 INTRODUCTION

1.1 SCOPE AND OBJECTIVE

1.2 SITE HISTORY

1.3 SITE GEOLOGY AND HYDROLOGY ix

REGULATORY CRITERIA

2.1 BACKGROUND

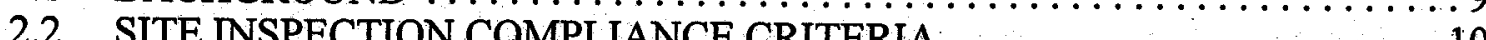

2.3 SOIL MOISTURE MONITORNG COMPLIANCE CR...............

3.0 SITE INSPECTIONS AND ANNUAL SUBSIDENCE SURVEY $\ldots \ldots \ldots \ldots \ldots 13$

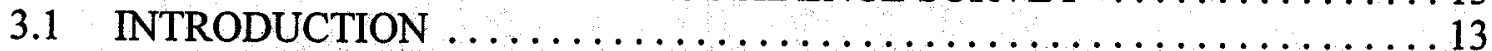

3.2 FINDINGS FROM MONTHLY INSPECTIONS $\ldots \ldots \ldots \ldots \ldots \ldots \ldots \ldots \ldots$

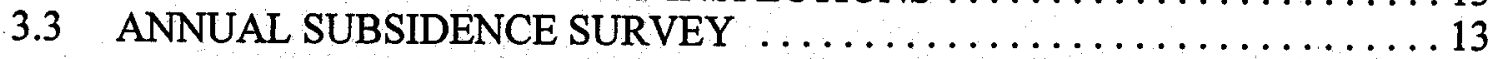

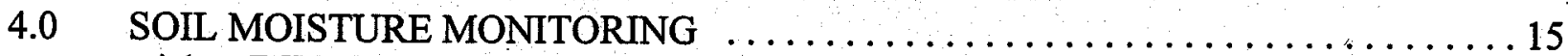

4.1 INTRODUCTION . ................................... 15

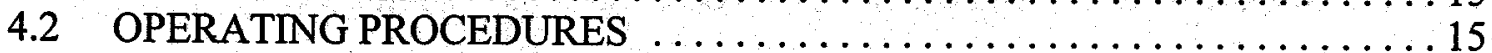

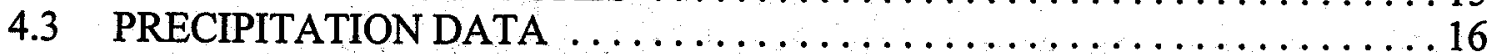

4.4 SOIL MOISTURE MONITORING RESULTS $\ldots \ldots \ldots \ldots \ldots \ldots \ldots \ldots \ldots \ldots$

4.4.1 Data Presentation ............................... 16

4.4.2 Discussion of Analytical Data Trends .................... 19

4.4.2.1 January 1998 - First Quarter ........................ 20

4.4.2.2 April 1998 - Second Quarter .................... 20

4.4.2.3 July 1998 - Third Quarter ..................... 20

4.4.2.4 October 1998 - Fourth Quarter ...................... 21

5.0 SUMMARY, CONCLUSIONS, AND RECOMMENDATIONS ..............27

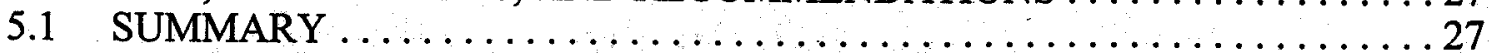

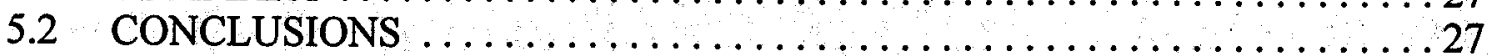

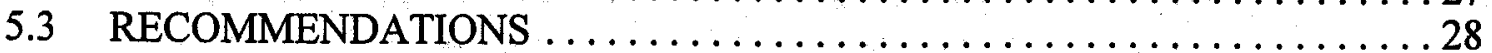

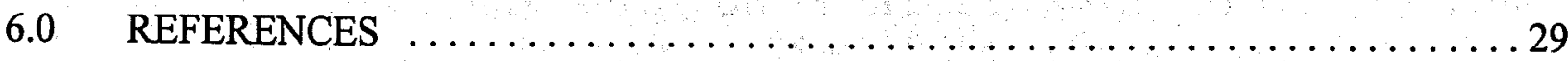




\section{TABLE OF CONTENTS (Continued)}

\section{APPENDICES}

APPENDIX A: POST-CLOSURE CARE INSPECTION CHECKLISTS

APPENDIX B: SUBSIDENCE SURVEY PLAT

APPENDIX C: PRECIPITATION RECORDS

DISTRIBUTION LIST

\section{FIGURES}

FIGURE 1 - SITE LOCATION MAP U-3fi $\ldots \ldots \ldots \ldots \ldots \ldots \ldots \ldots \ldots \ldots \ldots \ldots \ldots$

FIGURE 2 - CROSS SECTION OF THE U-3fi WASTE UNIT $\ldots \ldots \ldots \ldots \ldots \ldots \ldots$

FIGURE 3 - MONTHLY PRECIPITATION $\ldots \ldots \ldots \ldots \ldots \ldots \ldots \ldots \ldots \ldots \ldots \ldots$

FIGURE 4 - ER3-3 CUMULATIVE RESIDUAL NEUTRON COUNTS . . . . . . . . . . 22

FIGURE 5 - ER3-3 BASELINE DIFFERENCE FIRST QUARTER . . . . . . . . . 23

FIGURE 6 - ER3-3 BASELINE DIFFERENCE SECOND QUARTER . . . . . . . . . . . 24

FIGURE 7 - ER3-3 BASELINE DIFFERENCE THIRD QUARTER . . . . . . . . 25

FIGURE 8 - ER3-3 BASELINE DIFFERENCE FOURTH QUARTER . . . . . . . . . 26

\section{TABLES}

TABLE 1 - CHRONOLOGY OF THE AREA 3 U-3fi WASTE UNIT $\ldots \ldots \ldots \ldots$

TABLE 2 - SUBSIDENCE MONUMENT U-3fi COORDINATES AND ELEVATIONS . . . 14

TABLE 3 - PRECIPITATION DATA FOR THE BUSTER JANGLE Y, METEOROLOGICAL STATION BJY, AREA 3, NTS 


\section{ACRONYMS AND ABBREVIATIONS}

$\begin{array}{ll}\text { bgs } & \text { below ground surface } \\ \text { BN } & \text { Bechtel Nevada } \\ \text { BJY } & \text { Buster Jangle Y } \\ \mathrm{cm} & \text { centimeter(s) } \\ \text { DOE } & \text { U.S. Department of Energy } \\ \text { DOE/NV } & \text { U.S. Department of Energy, Nevada Operations Office } \\ \mathrm{ft} & \text { foot (feet) } \\ \text { in } & \text { inch(es) } \\ \mathrm{km} & \text { kilometer(s) } \\ \text { LANL } & \text { Lawrence Livermore National Laboratory } \\ \mathrm{m} & \text { meter(s) } \\ \text { mi } & \text { mile(s) } \\ \text { NDEP } & \text { Nevada Division of Environmental Protection } \\ \text { NTS } & \text { Nevada Test Site } \\ \text { RCRA } & \text { Resource Conservation and Recovery Act } \\ \text { REECo } & \text { Reynolds Electrical and Engineering Company, Inc. }\end{array}$


THIS PAGE INTENTIONALLY LEFT BLANK 


\section{ABSTRACT}

This annual Neutron Soil Moisture Monitoring report provides an analysis and summary for site inspections, meteorological information, and neutron soil moisture monitoring data obtained at the U-3fi Resource Conservation and Recovery Act Unit, located in Area 3 of the Nevada Test Site, Nye County, Nevada, during the October 1997 - October 1998 period.

Inspections of the U-3fi Resource Conservation and Recovery Act Unit are conducted to determine and document the physical condition of the concrete pad, facilities, and any unusual conditions that could impact the proper operation of the waste unit closure.

The objective of the neutron logging program is to monitor the soil moisture conditions along the 128 meter (m) (420 feet [ft]) ER3-3 monitoring well and detect changes that may be indicative of moisture movement in the regulated interval extending between 73 to $82 \mathrm{~m} \mathrm{(240} \mathrm{to} 270 \mathrm{ft})$ or to detect changes that may be indicative of subsidence within the disposal unit itself.

Physical inspections of the closure were completed in March and September 1998 and indicated that the site is in good condition with no significant findings noted.

The annual subsidence survey has noted a small subsidence of approximately 0.762 centimeter $(0.025 \mathrm{ft})$ which could be due to either incremental survey errors or represent an actual subsidence. The question of the source of this apparent subsidence will be resolved by observing trends over the next several annual subsidence surveys.

Soil moisture monitoring results indicate dry stable conditions for all quarterly monitoring periods. The Residual Raw Neutron Counts remain below the compliance Action Level of 200 counts within the regulated interval of 73 to $82 \mathrm{~m}$ ( 240 to $270 \mathrm{ft}$ ) for period from October 1997 through October 1998. 


\section{THIS PAGE INTENTIONALLY LEFT BLANK}




\section{PROJECT SUMMARY}

\section{INTRODUCTION}

This annual Neutron Soil Moisture Monitoring report provides an analysis and summary for site inspections, meteorological information, and neutron soil moisture monitoring data obtained at the U-3fi Resource Conservation and Recovery Act Unit, located in Area 3 of the Nevada Test Site, Nye County, Nevada, during the October 1997 - October 1998 period.

Inspections of the U-3fi Resource Conservation and Recovery Act Unit are conducted to determine and document the physical condition of the concrete pad, facilities, and any unusual conditions that could impact the proper operation of the waste unit closure.

The objective of the neutron logging is to monitor the soil moisture conditions along the 128 meter $(\mathrm{m})$ (420 feet [ft]) ER3-3 monitoring well and detect changes that may be indicative of moisture movement in the regulated interval extending between 73 to $82 \mathrm{~m}(240$ to $270 \mathrm{ft})$.

\section{REGULATORY CRITERIA}

Soil moisture compliance monitoring is done following the May 31, 1997 Class One Modification of the Nevada Division of Environmental Protection Permit for a Hazardous Waste Management Facility. Permit Number NEV HW009. The Class One Permit Modification incorporated the criteria presented in the December, 1996 letter (U.S. Department of Energy, 1996) requesting changes in the Resource Conservation and Recovery Act Industrial Sites Environmental Restoration Post Closure Plan. Area 3 U-3fi Waste Unit; August 1995.

The ER3-3 post closure monitoring criteria requires notification to the Nevada Division of Environmental Protection (NDEP) if the residual raw neutron counts (Observed Raw Counts minus Baseline Raw Counts) exceeds the 200 count Action Level in the regulated interval extending between 73 to $82 \mathrm{~m} \mathrm{(240} \mathrm{to} 270 \mathrm{ft}$ ) for two or more consecutive quarterly monitoring periods.

The ER3-3 post closure monitoring criteria also requires notification to the NDEP if settling in the U-3fi borehole has occurred on a scale large enough to cause shearing of the lower portion of the ER3-3 Monitoring Well. 


\section{RESULTS OF INSPECTIONS AND THE MONITORING PROGRAM}

\section{Inspections}

Site inspections are done every six months. No significant concerns were observed.

\section{Subsidence Survey}

The baseline elevation control survey for the subsidence markers was done in September 1995. This survey did not close as is required to determine survey error and, as a result, this survey could not be used for baseline purposes. The September 1996 subsidence survey was substituted for the control survey. The monument elevation was $1,230.837 \mathrm{~m}(4,038.18 \mathrm{ft})$. The first subsidence data were collected in July 1997 and indicated no detectable subsidence. The second annual subsidence survey in August 1998 is in English units with three places of precision. This survey indicated a monument elevation of $1,230.828 \mathrm{~m}(4,038.151 \mathrm{ft})$ indicating a subsidence of 0.884 centimeter $(\mathrm{cm})(0.029 \mathrm{ft})$. A second survey was conducted in September 1998 which resulted in a monument elevation of $1,230.831 \mathrm{~m}(4,038.159 \mathrm{ft})$ indicating a $0.640 \mathrm{~cm}(0.021 \mathrm{ft})$ subsidence which confirmed the previous survey result of approximately $0.61 \mathrm{~cm}(0.02 \mathrm{ft})$ subsidence. A visual inspection of the cover did not indicate any sign of subsidence. The survey closure error was $0.579 \mathrm{~cm}(0.019 \mathrm{ft})$. This small subsidence is suspected to be due to incremental instrument errors and errors with the previous survey rather than actual subsidence. The actual cause will be determined from additional annual surveys. If the subsidence continues to accumulate, it can be attributed to actual subsidence. If future surveys remain stable, this monitoring period's "subsidence" can be attributed to survey error.

\section{Precipitation}

Precipitation data was collected from the National Weather Service Nuclear Support Office's Meteorological Station Buster Jangle Y $37^{\circ} 03^{\prime} 46^{\prime}$ ' N, $116^{\circ} 03^{\prime} 09^{\prime \prime} \mathrm{W}$ in Area 3, Nevada Test Site, Nevada. This station is located approximately 4.8 kilometers $(\mathrm{km})(3$ miles [mi]) Northwest of the ER3-3 well.

The total yearly precipitation for the reporting period October 1997 through October 1998 was $39.73 \mathrm{~cm}$ (15.64 inches [in]). Annual precipitation (January 1998 through October 1998) is already at $37.06 \mathrm{~cm}(14.59 \mathrm{in})$ reported with two months remaining in the calendar year. The previous historic record (from 1960 to present) was $34.95 \mathrm{~cm}$ (13.76 in) which occurred in the January 1983 through December 1983 period. This record rainfall is the result of El Nino weather patterns and represents the wettest conditions ever recorded at this site.

\section{Soil Moisture Monitoring}

The Cumulative Residual Neutron Counts graph (Figure PS-1) tracks changes over time from baseline conditions relative to the regulatory level of concern. The Residual Raw Counts are calculated by subtracting the raw neutron count of each monitoring period from the first-year average neutron count (Baseline). While the data are collected on a $0.3 \mathrm{~m}(1 \mathrm{ft})$ interval, the Cumulative Residual Neutron Count graph only presents the residual count every $1.5 \mathrm{~m}(5 \mathrm{ft})$ in 
The next four graphs (Figures PS-2 through PS-5) show the Baseline Difference for successive quarterly monitoring periods along the entire length of a neutron access tube relative to baseline conditions. These are calculated by subtracting the Baseline (first-year average) raw neutron count from the current raw neutron count on a depth basis. The result of this subtraction is referred to as the Residual Raw Count. The Residual Raw Count is plotted along with the actual Raw Neutron Counts of both the current and baseline data vs Depth from the top of the casing. A positive residual neutron count indicates conditions at that depth and point in time that are wetter than baseline conditions, while negative values indicate dryer conditions.

The Baseline Difference graphs provide detailed information on the overall performance of the entire unit.

The Cumulative Residual graph focuses only on cumulative trends relative to the regulatory level of concern within the regulated interval and is used to determine regulatory compliance.

\section{SUMMARY}

- Inspections of the cover were done to identify any significant changes to the unit requiring action. No significant concerns were noted.

- The first baseline subsidence survey was conducted on July 30, 1997. Comparison of the baseline and August 1998 subsidence surveys indicate $0.884 \mathrm{~cm}(0.029 \mathrm{ft})$ subsidence. A confirmation survey was run in September and indicated $0.640 \mathrm{~cm}(0.021 \mathrm{ft})$ subsidence. The measured subsidence may be due to either incremental survey errors or an actual subsidence of the monument. If subsequent surveys indicate no change in subsidence, this subsidence can be attributed to survey errors in the baseline survey. If a trend is found that continues in future surveys, the result can attributed to actual subsidence.

- Visual inspections of the cover revealed no evidence of subsidence.

- The area immediately beneath the cement plug shows an air gap with apparent "drying" which is probably due to the settling of the backfill in this area. The apparent drying trend remains at $17.9 \mathrm{~m}(59 \mathrm{ft})$ in the January and subsequent monitoring quarters and its extent is unchanged from the October 1997 monitoring period.

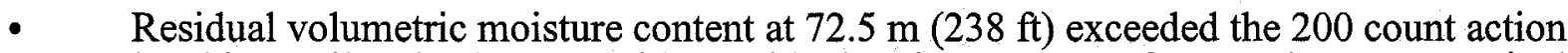
level in April and July 1998 with a residual moisture count of 219 and 203, respectively. This depth is not in the regulated interval of 73.2 to $82.3 \mathrm{~m}(240$ to $270 \mathrm{ft})$. These higher counts occur in an area with a significant change in the lithology and can be attributed to positioning errors due to cable stretch or a slightly different length in the new logging cable. The cable will be stretched and the depth markers recalibrated

The ER3-3 neutron moisture data obtained in 1998 are below the Action Level of 200 residual raw counts within the regulated interval. 


\section{ER3-3 Soil Moisture Monitoring}

Cumulative Residual Neutron Counts

July 1995 through October 1998
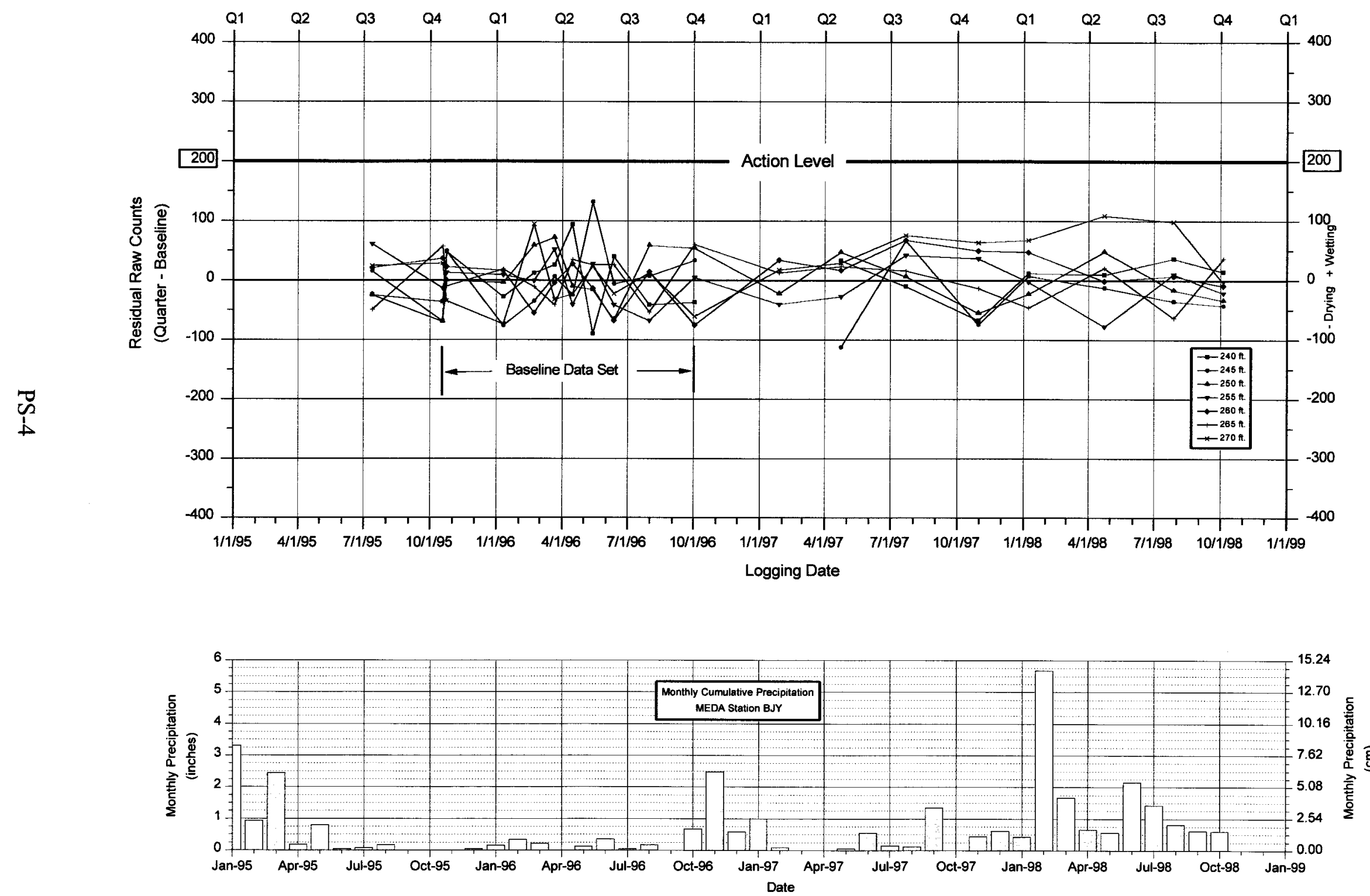


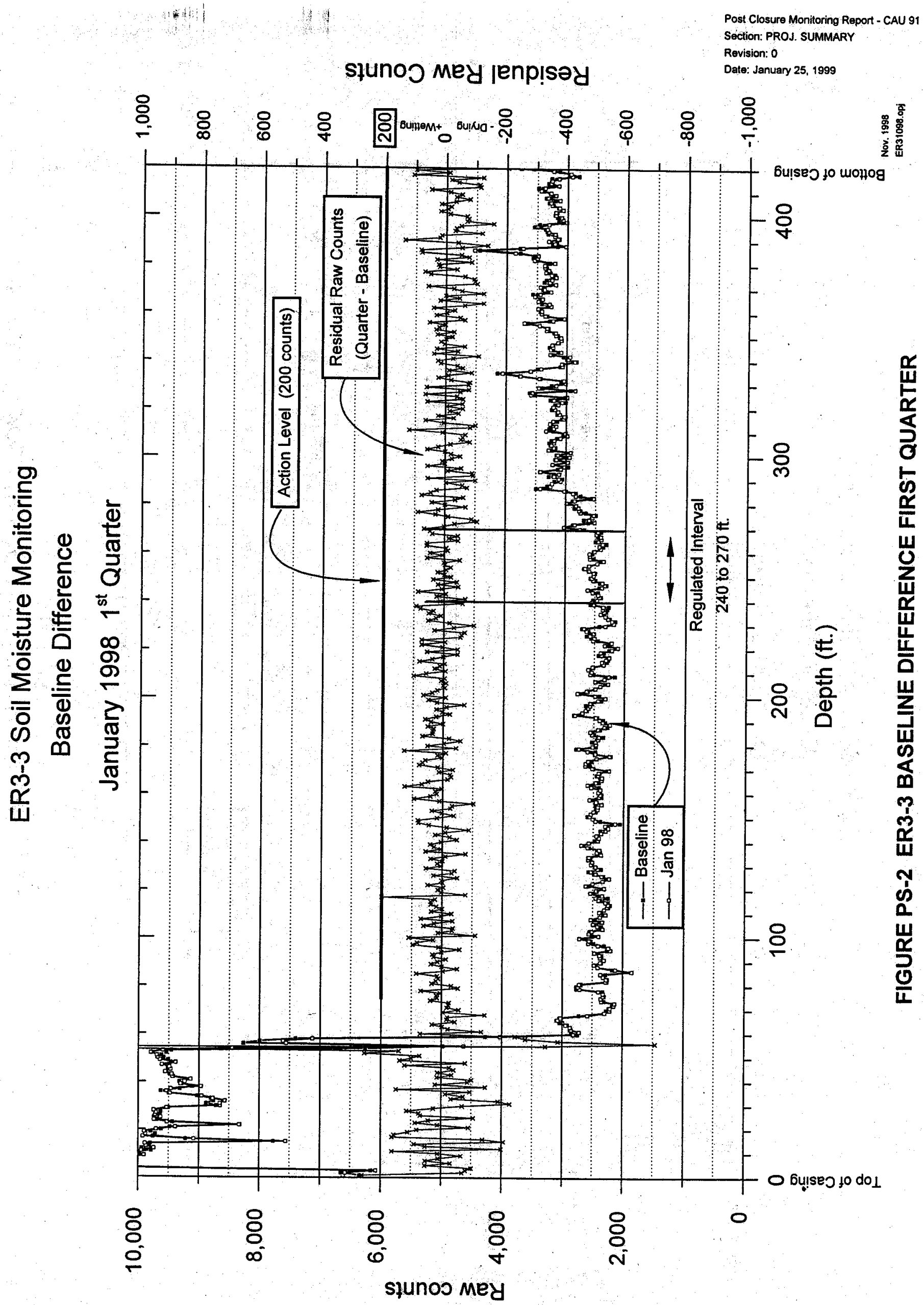




\section{ER3-3 Soil Moisture Monitoring \\ Baseline Difference}

April $19982^{\text {nd }}$ Quarter

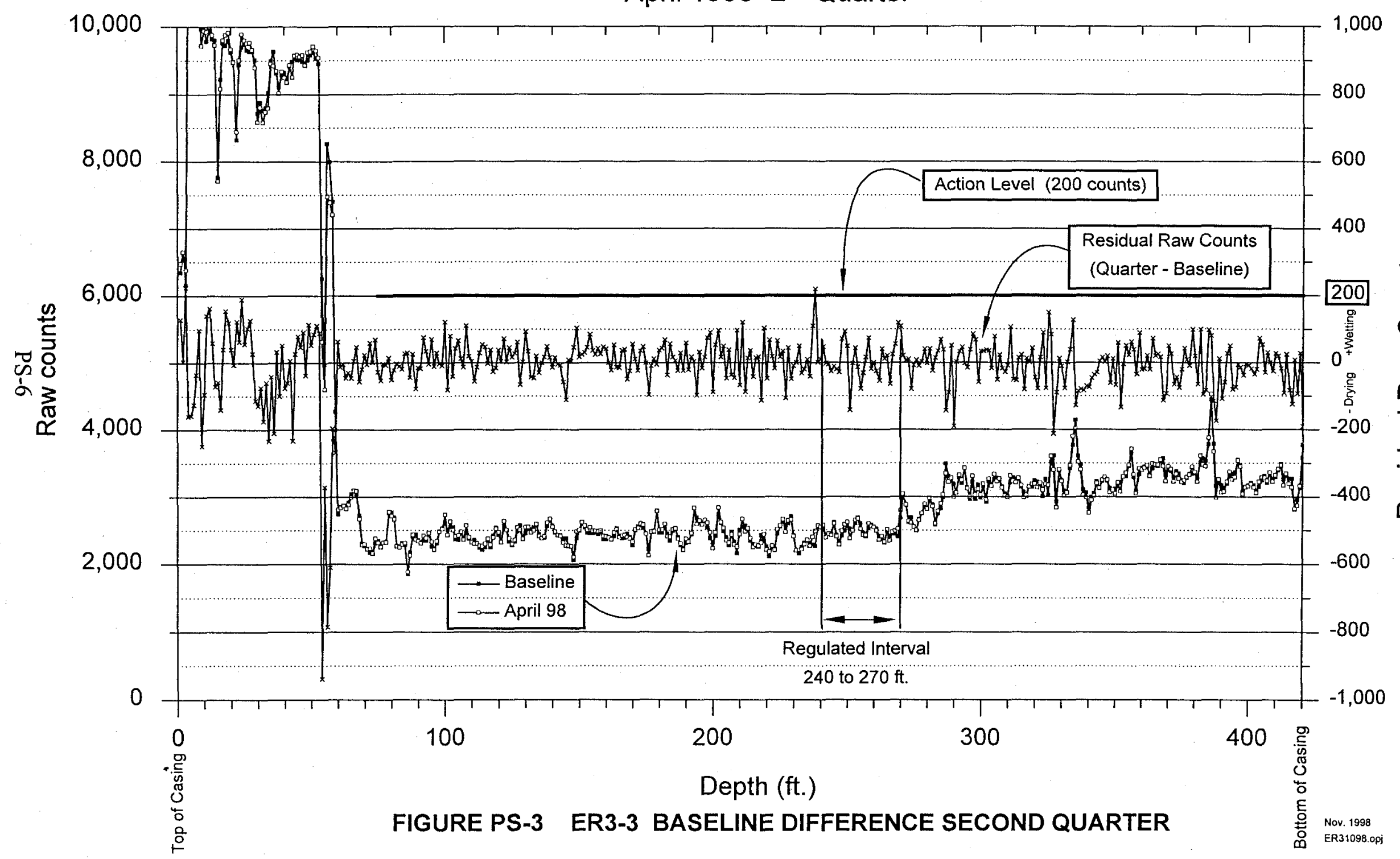




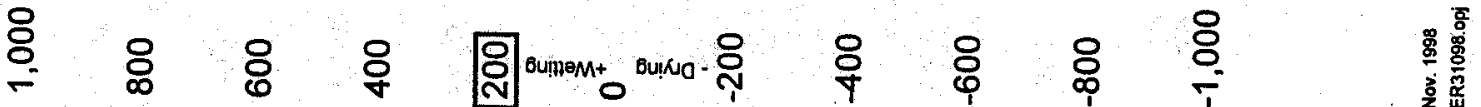

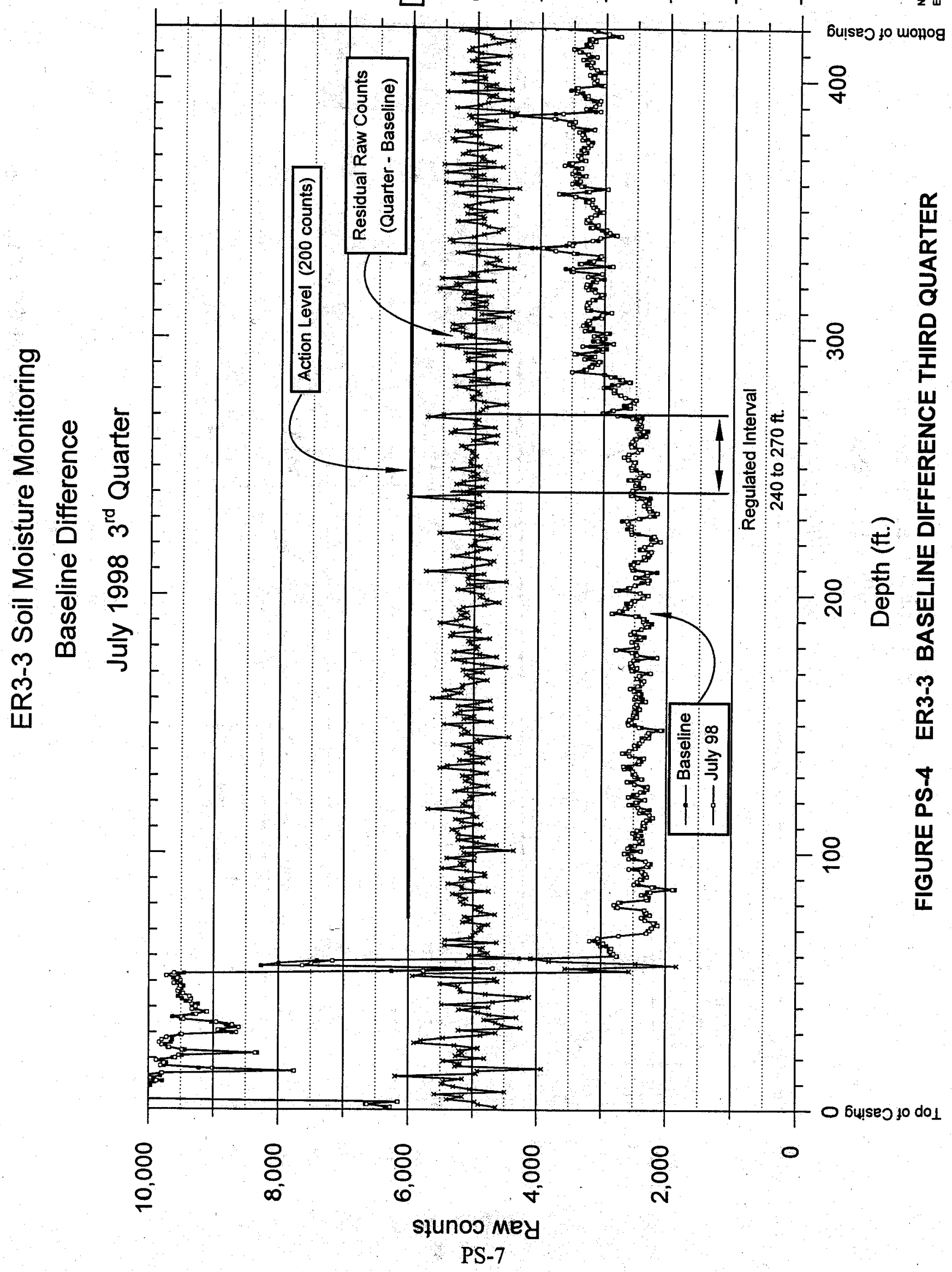




\section{ER3-3 Soil Moisture Monitoring}

Baseline Difference

October $19984^{\text {th }}$ Quarter

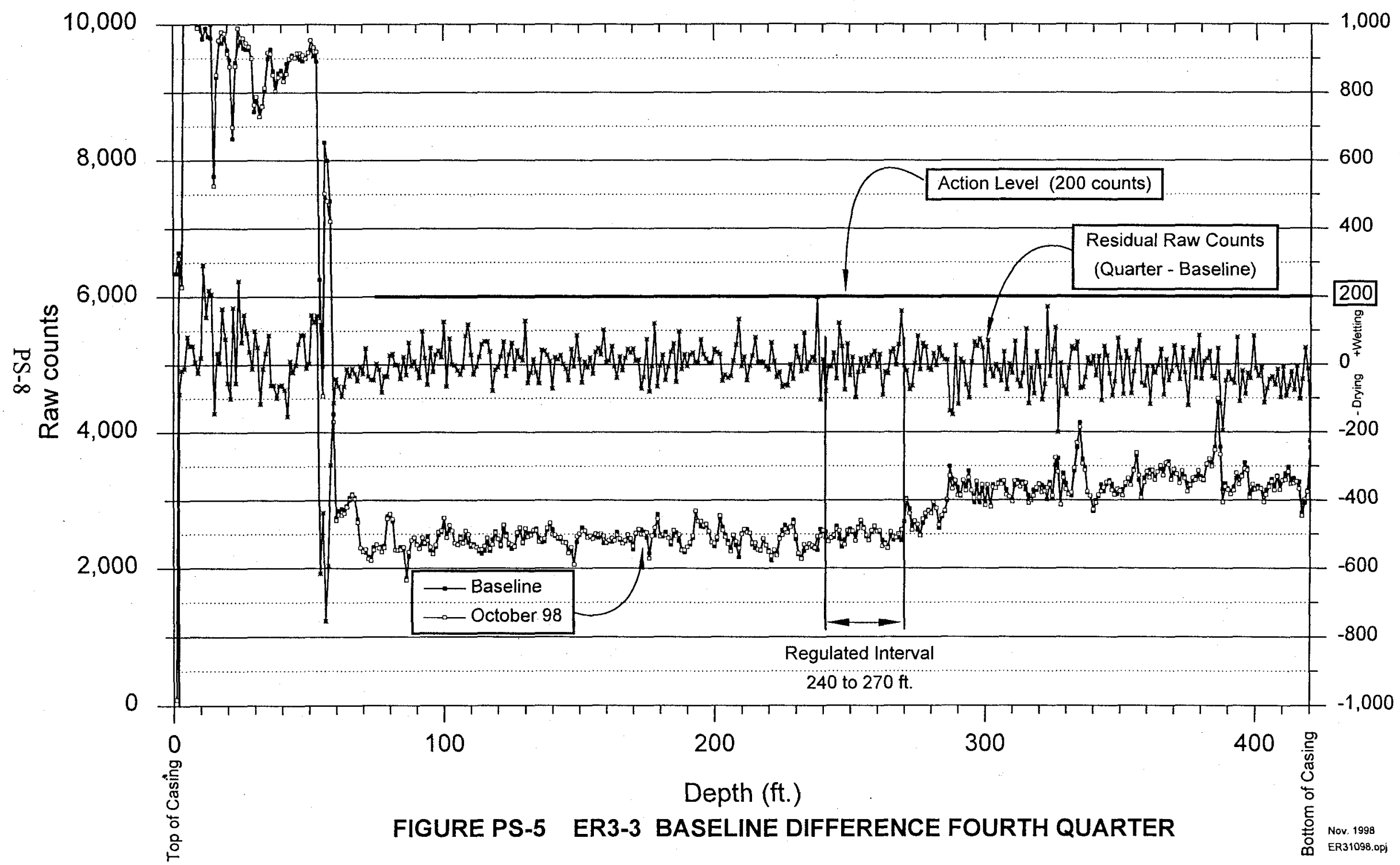




\section{CONCLUSIONS}

- No significant concerns were observed during the site inspections over the period October 1997 through October 1998.

- The subsidence survey and visual inspections have detected approximately $0.762 \mathrm{~cm}$ $(0.025 \mathrm{ft})$ subsidence in the closure cap. It is not clear if this is due to survey errors or actual subsidence.

- Both the Baseline Difference and Cumulative Residual data indicate dry stable conditions for all quarterly monitoring periods. The Residual Raw Neutron Counts remain below the compliance Action Level of 200 counts within the regulated interval for period from October 1997 through October 1998.

- The closure is in compliance and performing as designed.

\section{RECOMMENDATIONS}

- Although not within a compliance interval, or of regulatory concern, the drying trend observed in the bentonite seal and sloughed soils beneath the cement well head protection plug will continue to be monitored to determine if the trend represents a void or drying trend within this material.

- Future subsidence surveys need to address the question of whether the observed $0.762 \mathrm{~cm}$ $(0.025 \mathrm{ft})$ subsidence is due to survey error or actual subsidence. Because the apparent subsidence is so small, tight survey control will be needed for future surveys in order to resolve the question.

- In an effort to minimize the number of one-point positioning errors observed in the logs, the logging cable will be suspended with a weight to pre-stretch the cable before recalibrating the depth markers. 


\section{THIS PAGE INTENTIONALLY LEFT BLANK}

PS-10 


\subsection{INTRODUCTION}

\subsection{SCOPE AND OBJECTIVE}

This annual neutron soil moisture monitoring report provides an analysis and summary for site inspections, meteorological information, and neutron soil moisture monitoring data obtained at the U-3fi Resource Conservation and Recovery (RCRA) Unit, located in Area 3 of the Nevada Site (NTS), Nye County, Nevada. This is the second annual report on the U-3fi Closure and covers the period October 1997 to October 1998.

Inspections of the U-3fi RCRA Unit are conducted to determine and document the physical condition of the covers, facilities, and any unusual conditions that could impact the proper operation of the waste unit closure.

The objective of the neutron-logging program is to monitor the stability in soil moisture conditions along the 128 meters $(\mathrm{m})$ (420 feet [ft]) ER3-3 well and detect changes that may be indicative of moisture movement in the regulated interval of 73.2 to $82.3 \mathrm{~m}$ ( 240 to $270 \mathrm{ft}$ ).

\subsection{SITE HISTORY}

The U-3fi Waste Unit is located in Area 3 at the NTS, Nye County, Nevada. The NTS is approximately 105 kilometers (km) (65 miles [mi]) northwest of Las Vegas, Nevada (Figure 1).

The U-3fi Waste Unit is an abandoned Los Alamos National Laboratory (LANL) emplacement hole (Figure 2). It was drilled by Reynolds Electrical \& Engineering Co., Inc. (REECo), between March 27, 1967 and April 24, 1967, for emplacement of a nuclear explosive device. A detailed history of the emplacement hole drilling program is found in the U-3fi Waste Unit Closure Plan (U.S. Department of Energy [DOE], 1995a). On April 11, 1967, the hole reached a depth of $256 \mathrm{~m}(841 \mathrm{ft})$ below the surface. Due to formation conditions, a thicker drilling foam was introduced to the hole. Unfortunately, this did not work and the hole started caving in and the drill bit was trapped at a depth of $254.8 \mathrm{~m}(836 \mathrm{ft})$. There were a number of attempts to retrieve the drill bit but all attempts failed. The top of the collapsed emplacement hole was found at $73.2 \mathrm{~m}(240 \mathrm{ft})$ below ground surface. The hole was abandoned on April 24, 1967.

The U-3fi Waste Unit was established in 1970 as a disposal site for radiologically contaminated waste primarily for postshot "high-grading" wash water, which was solidified with cement and drill cores (Tattro, 1989). 
Post Closure Monitoring Report - CAU No. 91 Section; INTRODUCTION

Revision: 0

Date: January 25, 1999

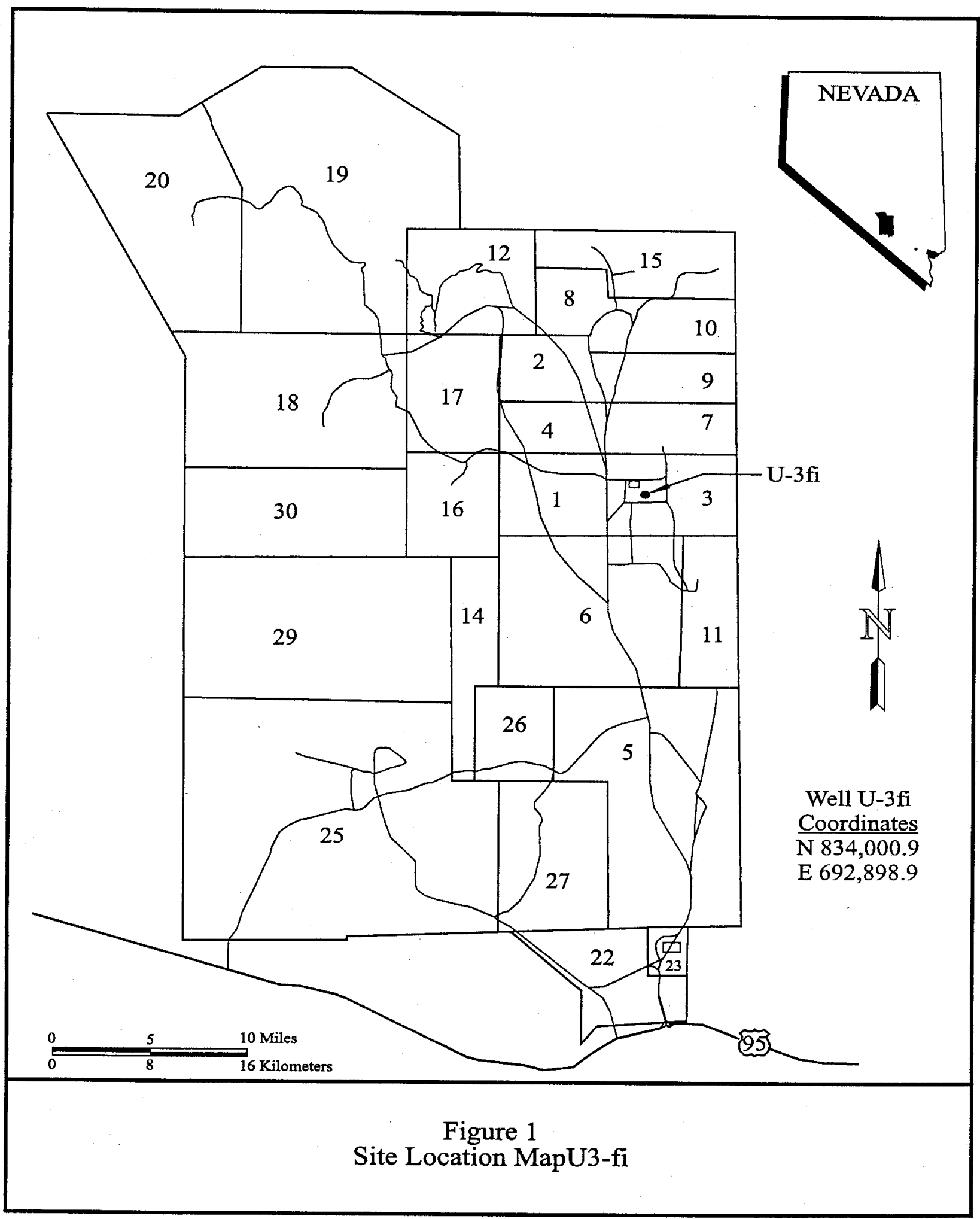




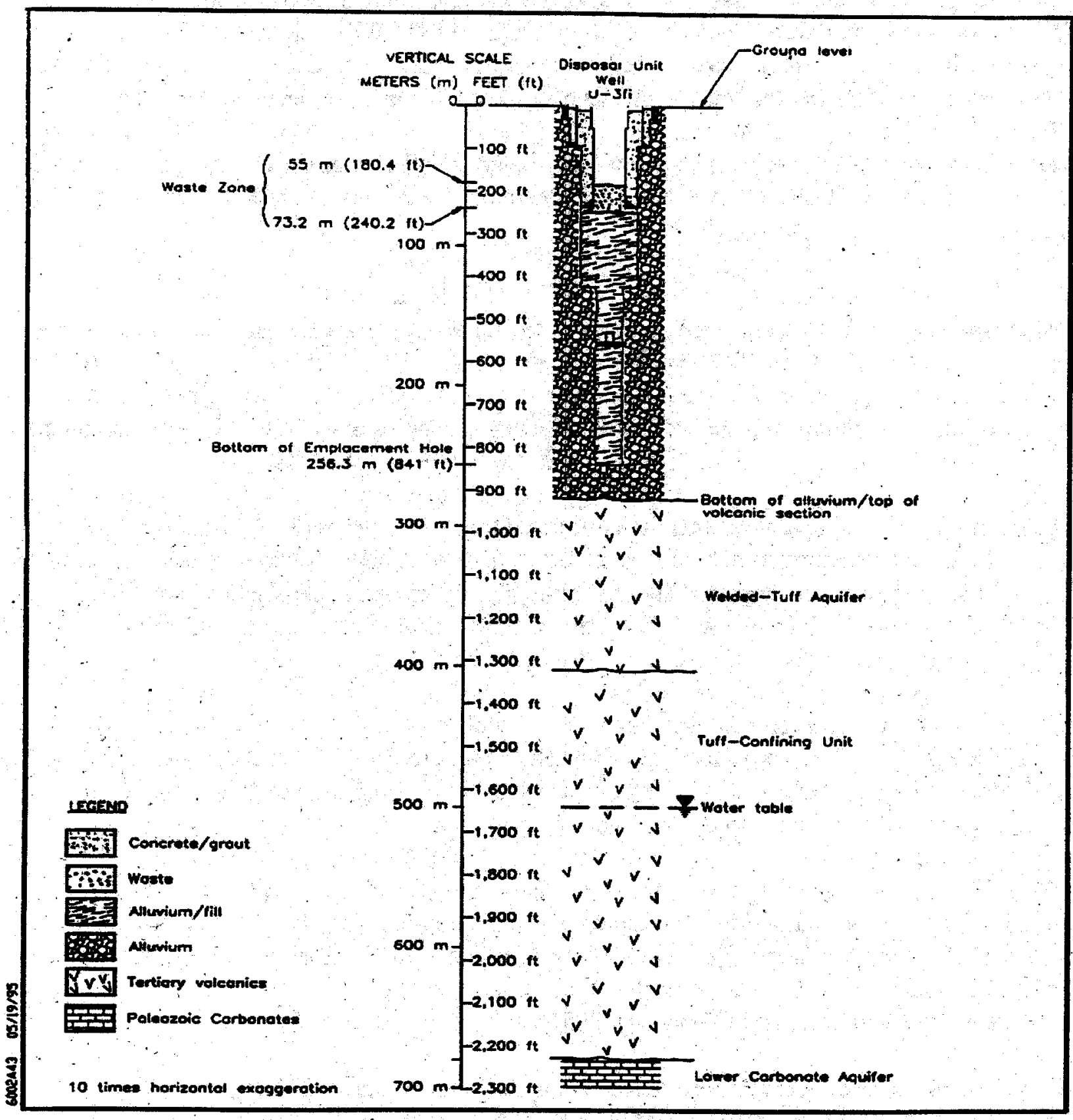

Figure 2

Cross Section of the U-3fi Waste Unit 
The U-3fi Waste unit primarily received core samples and solidified decontamination wastes. Core samples consisted of mixed fission and activation products from the solidification detonation debris/melt during postshot drilling (DOE, 1988). While under LANL control, only LANL solid drillback waste was disposed in the U-3fi Waste Unit. Control of the U-3fi Waste Unit was assumed in 1977 by the Atomic Energy Commission, later renamed the Energy Research and Development Administration, now the DOE. At this time, four additional waste generators, Lawrence Livermore National Laboratory (LLNL), Area 6 Decontamination Pad, Area 12 Tunnels, and LRY3 (an unspecified generator of weapons test program waste), began disposing their waste in the U-3fi Waste Unit.

Waste disposal record keeping for the U-3fi Waste Unit began in 1977. The database, established and maintained by REECo Defense Waste Management Department, currently the Bechtel Nevada (BN) Waste Management Project, has 102 entries between January 11, 1977 and November 28, 1988. Access to the U-3fi Waste Unit from 1977 to 1989 was through both REECo Radiation Safety and Wackenhut Services, Inc. Copies of the waste disposal documents are found in Appendix C of the U-3fi Waste Unit Closure Plan (DOE, 1995a).

According to waste disposal records, it is estimated that 86.34 curies $(3,181$ gigabecquerel $)$ ( 1.7 kilograms [ 3.7 pounds]) of fission products from drilling activities were placed in the waste unit. Chromium from drilling mud and lead from pipe-lubricant, stemming, and shielding

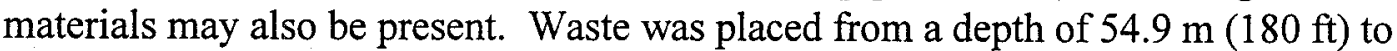
approximately $73.2 \mathrm{~m}$ (240 ft) below ground surface (bgs).

Subsurface characterization activities began in November 1994 with the installation of the ODEX borehole ER3-3. The objectives of this study were to determine if constituents of concern were present in the subsurface and to assess the potential for migration of these constituents of concern from the waste zone to the surrounding formation.

The ER3-3 Borehole is located $18.3 \mathrm{~m}$ (60 ft) south of U-3fi and drilled at a design angle of six degrees from the vertical in order to intercept the U-3fi emplacement borehole at approximately $183 \mathrm{~m}(600 \mathrm{ft})$ bgs. In practice, the emplacement borehole was intercepted at a depth of $125 \mathrm{~m}$ $(410 \mathrm{ft}) \mathrm{bgs}$ due to drilling conditions that increased the borehole angle. The borehole reached a total depth of $130 \mathrm{~m}$ (425 ft) in February 1995.

Cuttings and core samples were recovered during drilling operations that were used to understand the geologic, lithologic, and hydrologic soil properties surrounding the U-3fi waste unit. The results of these studies are discussed in the U-3fi Post-Closure Plan (DOE, 1995b).

The ER3-3 Borehole was completed as a neutron-probe soil moisture monitoring well by removing the ODEX casing and stemming a single wall steel casing in place with a sand backfill. The monitoring well is located entirely within the vadose zone and extends from the surface to a depth of $128 \mathrm{~m}$ (420 ft). Its purpose is to provide post-closure monitoring for changes in soil moisture content that would indicate moisture migration in the vicinity of the waste and to detect subsidence of material in the U-3fi Borehole. 
The Closure Plan (DOE, 1995b) was approved by the Nevada Division of Environmental Protection (NDEP) on August 28, 1995. The DOE Project Manager authorized closure of the waste unit at that time.

On September 6,1995, the stemming activities in U-3fi began with the placement of approximately $2.13 \mathrm{~m} \mathrm{(} 7 \mathrm{ft}$ ) of $20 / 40$ sand and an expanding cement grout plug $4.6 \mathrm{~m}(15 \mathrm{ft})$ thick. Once this plug was allowed to set, the casing was filled with $32.6 \mathrm{~m}(107 \mathrm{ft})$ of NTS fine stemming sand and grouted with an expanding cement plug $13.7 \mathrm{~m}(45 \mathrm{ft})$ thick. On September 28, 1995, the U-3fi unit was declared closed.

Post closure monitoring activities, detailed in the Post-Closure Plan (DOE, 1995b), specified that a neutron monitoring program was to be based upon monitoring and reporting changes in absolute moisture content. The Action Level criteria for tracking and reporting to the NDEP was specified as the observance of a five percent relative increase in volumetric moisture content for two or more consecutive monitoring periods. As originally designed, the ER3-3 well was to be used for obtaining raw neutron counts. This new specification would require a complicated and expensive compound calibration for determining absolute soil moisture content in the telescoping sand-packed borehole. In December 1995, representatives of NDEP, U.S. Department of Energy, Nevada Operations Office (DOE/NV), and Bechtel Nevada (BN) agreed that considering the $73.2 \mathrm{~m}(240 \mathrm{ft})$ depth of the regulated interval and the dry climatic conditions, no changes in moisture content would be expected. Therefore, the high cost of calibrating for the ER3-3 borehole geometry was not justified and a relatively simple program of monitoring for changes in raw counts would be sufficient as long as the alternative proposal was more conservative than the absolute Action Levels presented in the (unapproved) Closure Plan.

The first baseline neutron log from ER3-3 was obtained in July 19 . The first year of monitoring established baseline conditions. The first quarterly monitoring was conducted in October 1996.

In September 1996, DOE formally petitioned NDEP to change the Action Level to a 200-count change from baseline conditions in the 73.2 to $82.3 \mathrm{~m}(240$ to $270 \mathrm{ft})$ regulated interval. This request was based on a statistical analysis of the expected rate of occurrence of false positives and false negatives in a 20 -year period.

A Class One Modification to adjust the monitoring criteria in Section V of the Historic RCRA Units (NDEP, 1997) for the U-3fi Waste Unit was adopted on May 31, 1997.

Significant events for the U-3fi Waste Unit are summarized in Table 1. 
TABLE 1 - CHRONOLOGY OF THE AREA 3 U-3fi WASTE UNIT

\begin{tabular}{|c|c|}
\hline DATE & SIGNIFICANT EVENTS \\
\hline 1970 & $\begin{array}{l}\text { U-3fi Waste Unit established as disposal site for radiologically contaminated waste consisting of } \\
\text { solidified post-shot waste water and drill cores. }\end{array}$ \\
\hline 1989 & Waste no longer accepted for disposal in U-3fi \\
\hline \multirow[t]{2}{*}{1994} & $\begin{array}{l}\text { Resource Conservation and Recovery Act Site Characterization Plan Area } 3 \text { U-3fi Waste Unit } \\
\text { Draft issued November } 1994 .\end{array}$ \\
\hline & $\begin{array}{l}\text { Subsurface site characterization studies began in November } 1994 \text { with installation of borehole } \\
\text { ER3-3. Borehole was drilled } 13.3 \mathrm{~m}(60 \mathrm{ft}) \text { south of U-3fi at an angle of } 6^{\circ} \text { to a depth of } 130 \mathrm{~m} \\
(425 \mathrm{ft}) .\end{array}$ \\
\hline \multirow{6}{*}{1995} & $\begin{array}{l}\text { Resource Conservation and Recovery Act Industrial Site Environmental Restoration Closure } \\
\text { Plan, Area 3 U-3fi Waste Unit, Draft issued June } 1995 .\end{array}$ \\
\hline & $\begin{array}{l}\text { Resource Conservation and Recovery Act Industrial Sites Environmental Restoration Post } \\
\text { Closure Plan, Area 3 U-3fi Waste Unit; issued August } 1995\end{array}$ \\
\hline & First year neutron baseline data set started in July. \\
\hline & September 6, 1995 stemming and grouting activities begin in U-3fi \\
\hline & September 28, 1995 U-3fi Unit was declared closed. \\
\hline & $\begin{array}{l}\text { Area } 3 \text { U-3fi Waste Unit Resource Conservation and Recovery Act Closure Report issued } \\
\text { November } 1995 .\end{array}$ \\
\hline \multirow[t]{2}{*}{1996} & $\begin{array}{l}\text { DOE petitions NDEP to change the Action Level to a change of } 200 \text { counts above baseline } \\
\text { conditions in the regulated interval. }\end{array}$ \\
\hline & First quarterly monitoring began in October 1996 \\
\hline \multirow{3}{*}{1997} & $\begin{array}{l}\text { First Annual Report RCRA Post-Closure Monitoring and Inspections for the U-3fi Waste Unit for } \\
\text { the Period July } 1995 \text { - October } 1996 \text { was issued in January } 1997\end{array}$ \\
\hline & $\begin{array}{l}\text { A Class One Modification to adjust the monitoring criteria in Section V of the Historic RCRA } \\
\text { Units (Permit No. NEV HW009) for the U-3fi Waste Unit was adopted on May 31,1997. }\end{array}$ \\
\hline & $\begin{array}{l}\text { During first quarter logging the neutron logging tool } \# 7074 \text { separated from cable and was } \\
\text { irreparably damged in the fall. A back up instrument was calibrated to replace } \# 7074 \text {. }\end{array}$ \\
\hline
\end{tabular}




\subsection{SITE GEOLOGY AND HYDROLOGY}

The U-3fi Waste Unit is located in the west central portion of Yucca Flat in Area 3 of the NTS, Nye County, Nevada (834004 N, 692900 E).

Yucca Flat is located within the Ash Meadows groundwater subbasin (Waddel, 1982). Regional groundwater flow is assumed to be south-southwest. Discharge occurs primarily in Ash Meadows, located approximately $80 \mathrm{~km}(50 \mathrm{mi})$ to the south-southwest.

The U-3fi emplacement hole extends to approximately $256 \mathrm{~m}(841 \mathrm{ft})$ and is hosted in Quaternary and Tertiary alluvial deposits which extend locally to about $274 \mathrm{~m}(900 \mathrm{ft})$. These deposits are variably cemented, moderately sorted sand and gravel derived from local hills. Beneath the alluvium, a Tertiary volcanic sequence extends from about $274 \mathrm{~m}(900 \mathrm{ft})$ to about $671 \mathrm{~m}(2,200 \mathrm{ft})$. These rocks form two hydrogeologic units; the welded tuff aquifer and the tuff- confining unit (Winograd and Thordarson, 1975). The water table beneath U-3fi occurs within the tuff-confining unit at approximately $488 \mathrm{~m}(1,600 \mathrm{ft})$. Underlying the volcanic sequence is the Lower Carbonate Aquifer, which is comprised of Paleozoic limestones and dolomites. These rocks are complexly faulted and form the primary groundwater transport path towards the Ash Meadows discharge point. The lower carbonate aquifer is estimated to be approximately $1,000 \mathrm{~m}(3,300 \mathrm{ft})$ thick beneath the U-3fi unit. Vertical migration of groundwater beneath $U-3 f i$ is controlled by the tuff-confining unit. Lateral (regional) migration is controlled by the lower carbonate aquifer.

Annual precipitation at Well ER6-1, located approximately $10 \mathrm{~km}(6.2 \mathrm{mi})$ south of U-3fi, is 12.52 centimeters $(\mathrm{cm})$ ( 4.93 inches [in]). Estimates of Potential Evapotranspiration obtained from characterization studies in Area 5 indicate Potential Evapotranspiration of about 157.5 centimeters/year (62 inches/year), which is significantly higher than the mean annual precipitation (DOE, 1995c). Recharge to the subsurface is believed to be nonexistent. 
THIS PAGE INTENTIONALLY LEFT BLANK 


\subsection{BACKGROUND}

Section 4.0 of the Post Closure Plan (DOE, 1995b) specified a neutron monitoring program that is to be based upon monitoring and reporting changes in absolute volumetric soil moisture content. An action criteria for tracking and reporting to the NDEP was specified (Section 4.1.2) as the observance of a five percent relative increase in volumetric moisture content for more than two consecutive monitoring periods. Because the well was designed for obtaining raw neutron counts, this specification would have required a complicated and expensive compound calibration for determining absolute soil moisture content in the telescoping, sand-packed borehole. Implementation of this strategy would be both costly and problematic.

In a meeting with representatives from NDEP, DOE/NV, and BN in December 1995, it was requested by DOE/NV that the monitoring strategy be changed for two reasons. The first was that the benefits of obtaining a compound calibration for absolute moisture content are offset by the high cost of calibrating for the ER3-3 hole geometry. The second, considering the depth of the regulated interval and dry climatic conditions at the NTS, was that changes in moisture content are not expected. Therefore, a relatively simple program of monitoring for changes in raw neutron counts would be both conservative and sufficient. It was agreed that it did not make sense to calibrate the neutron probe for the ER3-3 geometry, but that any alternative proposal must be more conservative than the absolute volumetric moisture content Action Levels presented in the unapproved Post-Closure Plan. In addition, it was agreed to obtain up to 12 months of baseline neutron data and then propose an alternative monitoring plan to NDEP.

The proposed alternative to an absolute calibration was to use "statistically significant" changes in raw counts from the neutron tool to determine when an increase in moisture content occurred in the regulated interval.

The philosophy in using this approach is guided by two criteria:

1). Considering both the depth to the regulated interval and the arid site conditions, no change was expected due to surface rainfall events and infiltration. Therefore, any changes above the system noise level could be considered significant regardless of the change in absolute moisture content. Consequentially, calibration of the neutron gauge to local geometries and soil conditions would not be required.

2). Because the proposed monitoring is based on changes in raw counts, and not on the absolute moisture content, the criteria for setting an Action Level should be more conservative than what would be set when using an absolute soil moisture content. 
Considering the above-stated criteria, a conservative choice for the Action Level would be "any statistically significant changes greater than some small multiple of the system noise level." A statistical method called the Bootstrap (Bradley and Tibshirani, 1993) was run using the one-year baseline data set to provide the statistical character of the system noise and a 20 year acceptance rate of about two percent for both false positives and false negatives. The simulation was carried out to 2,000 years of quarterly monitoring ( 8,000 observations) in the 73.2 to $82.3 \mathrm{~m}$ ( 240 to $270 \mathrm{ft}$ ) regulated interval. For an acceptance rate of two percent, an Action Level of 200 count change from baseline conditions was found to meet the design criteria. Details of this process can be found in the first annual report (DOE, 1997) and a letter discussing the technical basis (DOE, 1996).

In October 1996, a formal proposal (DOE, 1996) from DOE was submitted to NDEP requesting that the post-closure monitoring activities be modified to reflect an Action Level based on a change in raw neutron counts of 200 counts in the regulated interval. NDEP approved this request on December 9, 1996 (NDEP, 1996).

A Class One Permit Modification incorporating the criteria provided in the December 1996 letter requesting changes in the Closure Plan (DOE, 1995b) was issued on May 31, 1997.

\subsection{SITE INSPECTION COMPLIANCE CRITERIA}

Prior to conducting a post-closure inspection, design drawings, aerial photographs, and site maintenance records are reviewed to provide a basis for evaluating site conditions. The site inspection includes a walking inspection of the entire site within $304 \mathrm{~m}(1,000 \mathrm{ft})$ of $\mathrm{U}-3 \mathrm{fi}$ and photo documentation. The Post-Closure Inspection Checklist (Appendix A) details items of concern under the following topics:

- Adjacent off-site features in the watershed areas up-slope of the Unit, such as new roads, and erosion channels.

- Access roads, fences, gates, and signs.

- Monuments and other permanent features.

- U-3fi waste cover.

- $\quad$ Site drainage features.

- $\quad$ Monitoring Well ER3-3. 


\subsection{SOIL MOISTURE MONITORING COMPLIANCE CRITERIA}

Soil moisture compliance monitoring is done following the May 31, 1997 Class One Modification of the NDEP permit for a Hazardous Waste Management Facility, Permit Number NEV HW009 (NDEP, 1997). The Class One Permit Modification incorporated the criteria presented in the December 1996 letter (DOE, 1996) requesting changes in the Post Closure Plan (DOE, 1995b).

The ER3-3 post-closure monitoring criteria requires notification to the NDEP if the residual raw neutron counts (Observed Raw Counts minus Baseline Raw Counts) exceeds the 200 count Action Level in the regulated interval extending between 73.2 to $82.3 \mathrm{~m} \mathrm{(240} \mathrm{to} 270 \mathrm{ft}$ ) for two or more consecutive quarterly monitoring periods. The post-closure monitoring criteria also requires notification to the NDEP if settling in the U-3fi borehole has occurred on a scale large enough to cause shearing of the lower portion of the ER3-3 monitoring well. 
是 


\subsection{SITE INSPECTIONS AND ANNUAL SUBSIDENCE SURVEY}

\subsection{INTRODUCTION}

To comply with the post-closure care requirements, formal site inspections have been done twice a year since the closure of the unit in September 1995. The inspections were completed to evaluate the performance and maintenance needs of the unit in accordance with the requirements of Title 40 Code of Federal Regulations $\$ 265.15$ and the RCRA Part B Permit. A complete inspection package includes copies of the inspection checklist, field logbook notes, site photographs, and the inspector's current resume. Copies of the Post-Closure Care inspection checklist and associated field notes for March 1998 and September 1998 are found in Appendix A. Copies of site photographs and inspectors' resumes can be obtained by contacting the U.S. Department of Energy, Environmental Restoration Division.

\subsection{FINDINGS FROM THE MONTHLY INSPECTIONS}

The site is in good condition and no significant findings were observed in either the March 1998 or September 1998 inspections.

\subsection{ANNUAL SUBSIDENCE SURVEY}

A subsidence monument was installed in the cement plug on the U-3fi cover and surveyed on September 18, 1995. This monument provides elevation control to determine if subsidence of the cement plug or soil surrounding U-3fi is occurring. The Subsidence Survey Plat is found in Appendix B.

On September 5, 1996, the first-year subsidence survey was conducted and determined that the original survey was invalid because the survey had been run without a proper closure (DOE, 1997). Becuase of this the September 5, 1996 survey, with a control elevation of $1,230.84 \mathrm{~m}$ $(4,038.18 \mathrm{ft})$, has been selected to represent the baseline elevation. All subsequent surveys will record subsidence relative to this datum.

A subsidence survey was completed on August 3, 1998, at the U-3fi monument. This elevation was recorded at $1,230.828 \mathrm{~m}(4,038.151 \mathrm{ft})$, which indicated a subsidence of $0.884 \mathrm{~cm}(0.029 \mathrm{ft})$. from the baseline control survey elevation of $1,230.84 \mathrm{~m}(4,038.18 \mathrm{ft})$ obtained on September 5 , 1996. A confirmation survey was run on September 1, 1998. This survey recorded a monument elevation of $1,230.831 \mathrm{~m}(4,038.159 \mathrm{ft})$, indicating a subsidence of $0.640 \mathrm{~cm}(0.021 \mathrm{ft})$. The survey had a closure error from the northwest corner monument of $0.579 \mathrm{~cm}(0.019 \mathrm{ft})$. Due to the small subsidence (approximately $0.635 \mathrm{~cm}$ [ $0.25 \mathrm{in}]$ ) it is unclear if this is a result of a 
previous survey error (incremental instrument error) or can be attributed to an actual subsidence of the monument itself. Future surveys should resolve this question by keeping tight control on the survey errors and monitoring for a continuing trend in subsidence of the magnitudes observed in this monitoring period.

Although the apparent subsidence noted here is not considered significant, it will be carefully monitored in future surveys.

TABLE 2 - SUBSIDENCE MONUMENT U-3fi COORDINATES AND ELEVATIONS

\begin{tabular}{|c|c|c|c|c|}
\hline \multirow{2}{*}{$\begin{array}{l}\text { SURVEY } \\
\text { DATE }\end{array}$} & \multicolumn{2}{|c|}{ COORDINATES' } & \multirow{2}{*}{$\begin{array}{l}\text { ELEVATION } \\
\text { TOP OF } \\
\text { MONUMENT } \\
\text { (Feet) }\end{array}$} & \multirow{2}{*}{$\begin{array}{l}\text { SUBSIDENCE } \\
\text { (Feet) }\end{array}$} \\
\hline & NORTHING & EASTIING & & \\
\hline September 18, 1995 & N 834004.0 & E 692900.3 & $(4038.1)^{C}$ & - \\
\hline September 5, 1996 & N 834004.00 & E 692900.35 & 4038.18 & - \\
\hline July 30, 1997 & N 834004.00 & E 692900.35 & 4038.18 & 0.00 \\
\hline August 3, 1998 & N 833001.43 & E 692900.35 & 4038.151 & -0.029 \\
\hline September $1,1998^{\mathrm{D}}$ & N 833001.43 & E 692900.35 & 4038.159 & -0.021 \\
\hline
\end{tabular}

A - All coordinates based on the Nevada State Plane Grid, Central Zone - North American Datum of 1983 in feet.

B - All elevations based on the North American Vertical Datum of 1929 in feet.

C - Elevation cannot be proven due to failure to perform a proper closure on the original survey.

September 5, 1996 survey will be used for the elevation control datum.

D - Re-run confirmation survey 


\subsection{SOIL MOISTURE MONITORING}

\subsection{INTRODUCTION}

The objective of the ER3-3 vadose zone monitoring program is to monitor the soil moisture condition in the 73.2 to $82.3 \mathrm{~m} \mathrm{(240} \mathrm{to} 270 \mathrm{ft}$ ) regulated interval to provide an early warning of the potential for leachate migration from U-3fi into the subsurface. In addition, the monitoring system is used to monitor changes indicative of subsurface subsidence within U-3fi.

The ER3-3 monitoring system uses a portable neutron moisture-logging tool to determine changes in the moisture content in soils surrounding neutron access tube which intercepts the U-3fi emplacement hole. By monitoring changes in soil moisture content, it is possible to detect the movement of wetting fronts in the soils surrounding the bottom of the U-3fi casing. The detection of changes in soil moisture content in this area provides an early warning of the potential movement of leachate from U-3fi to the surrounding environment, indicating possible failure of the grout plug.

The ER3-3 borehole is located $18.3 \mathrm{~m}$ (60 ft) south of U-3fi and drilled at a design angle of six degrees from the vertical. The U-3fi emplacement borehole was intercepted at a depth of

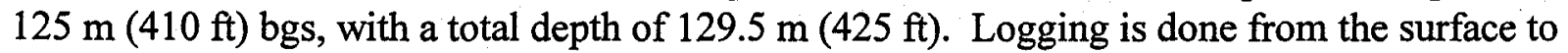

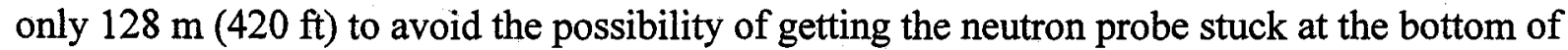
the access tube.

A Campbell Pacific Nuclear Hydroprobe (Model 503DR) containing a 50-millicurie (1.85-gigabecquerel) ${ }^{241} \mathrm{Americium} / \mathrm{Bery}$ llium neutron source is used to obtain moisture logs in the access tube. The tool is operated without a soil moisture calibration, recording raw neutron counts in a 16 -second window.

\subsection{OPERATING PROCEDURES}

Neutron-logging operations adhere to BN standard operating procedures. The logging procedure was modified so that the downhole tool can operate without a centralizer. This was done because the neutron access tube is inclined at a six-degree angle. Field quality control operations require a daily standard count test to be run at the start and end of the day. Failure to pass this statistical test requires stopping operations, notifying the supervisor, and determining the cause.

Using this procedure, neutron logs are obtained by lowering the neutron tool to within $1.5 \mathrm{~m}$ $(5 \mathrm{ft})$ of the bottom of the access tube. The raw neutron count is obtained using a 16-second count time at $0.3-\mathrm{m}(1-\mathrm{ft})$ intervals along the length of the access tube. The data is recorded on field $\log$ sheets and stored in the data logger of the neutron probe as raw counts. The data logger 
is then downloaded to a personnel computer on a daily basis. Once the data have been reviewed, they are presented as two graphs: Cumulative Residual Neutron Counts and Baseline Difference. These graphs are discussed in Section 4.4.1, Data Presentation.

\subsection{PRECIPITATION DATA}

Precipitation data was collected from the National Weather Service Nuclear Support Office's CLINET Station Buster Jangle Y (BJY) located at $37^{\circ} 03^{\prime} 46^{\prime}$ ' N, $116^{\circ} 03^{\prime} 09^{\prime \prime} \mathrm{W}$, in Area 3 of the NTS. This station is located approximately $4.8 \mathrm{~km}$ (3 $\mathrm{mi})$ northwest of Well ER3-3. Precipitation records for this station for the period October 1997 through October 1998 are found in Appendix C and summarized in Table 3 and Figure 3 (U.S. National Weather Service Nuclear Support Office, 1998).

The average annual precipitation over the period 1960 to 1998 at the BJY Station is $16.51 \mathrm{~cm}$ (6.50 in). The previous monitoring period, October 1996 to October 1997, recorded a yearly precipitation of $17.88 \mathrm{~cm}$ (7.04 in). Total yearly precipitation for the current monitoring period, October 1997 through October 1998, is $39.73 \mathrm{~cm}$ (15.64 in).

Annual precipitation (January 1998 through October 1998) is already at $37.06 \mathrm{~cm}$ (14.59 in) reported with two months remaining in the calendar year. The previous historic record (from 1960 to present) was $34.95 \mathrm{~cm}$ (13.76 in) for the January 1983 through December 1983 period. This new record rainfall is the result of El Nino weather patterns and represents the wettest conditions ever recorded at this site.

\subsection{SOIL MOISTURE MONITORING RESULTS}

\subsubsection{Data Presentation}

The Cumulative Residual Neutron Counts graph (Figure 4) tracks changes over time from baseline conditions relative to the regulatory level of concern (Action Level). The Residual Raw Counts are calculated by subtracting the first-year average neutron count (baseline) from the raw neutron count from each monitoring period. While the data are collected on a $0.3 \mathrm{~m}(1 \mathrm{ft})$ interval, the Cumulative Residual Neutron Count graph only displays the residual count every $1.5 \mathrm{~m}(5 \mathrm{ft})$ in the regulated interval between 73.2 to $82.3 \mathrm{~m} \mathrm{(240} \mathrm{to} 270 \mathrm{ft})$. This corresponds to the point closest to the bottom of the U-3fi emplacement casing. The residual values are plotted as Residual Raw Counts vs Date for each $1.5 \mathrm{~m}(5 \mathrm{ft})$ depth (Figure 4). The level of regulatory concern is indicated as a heavy line at the 200 count Action Level. Values exceeding this limit for two consecutive monitoring periods require notifying the NDEP as specified in the Part B RCRA Permit (NDEP, 1997). 


\section{TABLE 3 - PRECIPITATION DATA FOR THE BUSTER JANGLE $Y$, METEOROLOGICAL STATION BJY, AREA 3, NTS}

\begin{tabular}{|c|c|c|}
\hline DATE & $\begin{array}{l}\text { MONHHIY } \\
\text { QUMULATIVE } \\
\text { inches }^{\wedge}\end{array}$ & GUMULATIVE \\
\hline October 1997 & 0.0 & 0.0 \\
\hline November 1997 & $\cdots$ & 0.44 \\
\hline December 1997 & 0.61 & 1.05 \\
\hline January 1998 & 0.43 & 1.48 \\
\hline February 1998 & 5.68 & 7.16 \\
\hline March 1998 & 1.67 & 8.83 \\
\hline April 1998 & 0.66 & 9.49 \\
\hline May 1998 & 0.56 & 10.05 \\
\hline June 1998 & 2.16 & 12.21 \\
\hline July 1998 & 1.42 & 13.63 \\
\hline August 1998 & 0.81 & 14.44 \\
\hline September 1998 & 0.61 & 15.05 \\
\hline October 1998 & 0.59 & $15.64^{\mathrm{B}}$ \\
\hline
\end{tabular}

A - Source National Weather Service Nuclear Support Office.

B - New all time record precipitation 


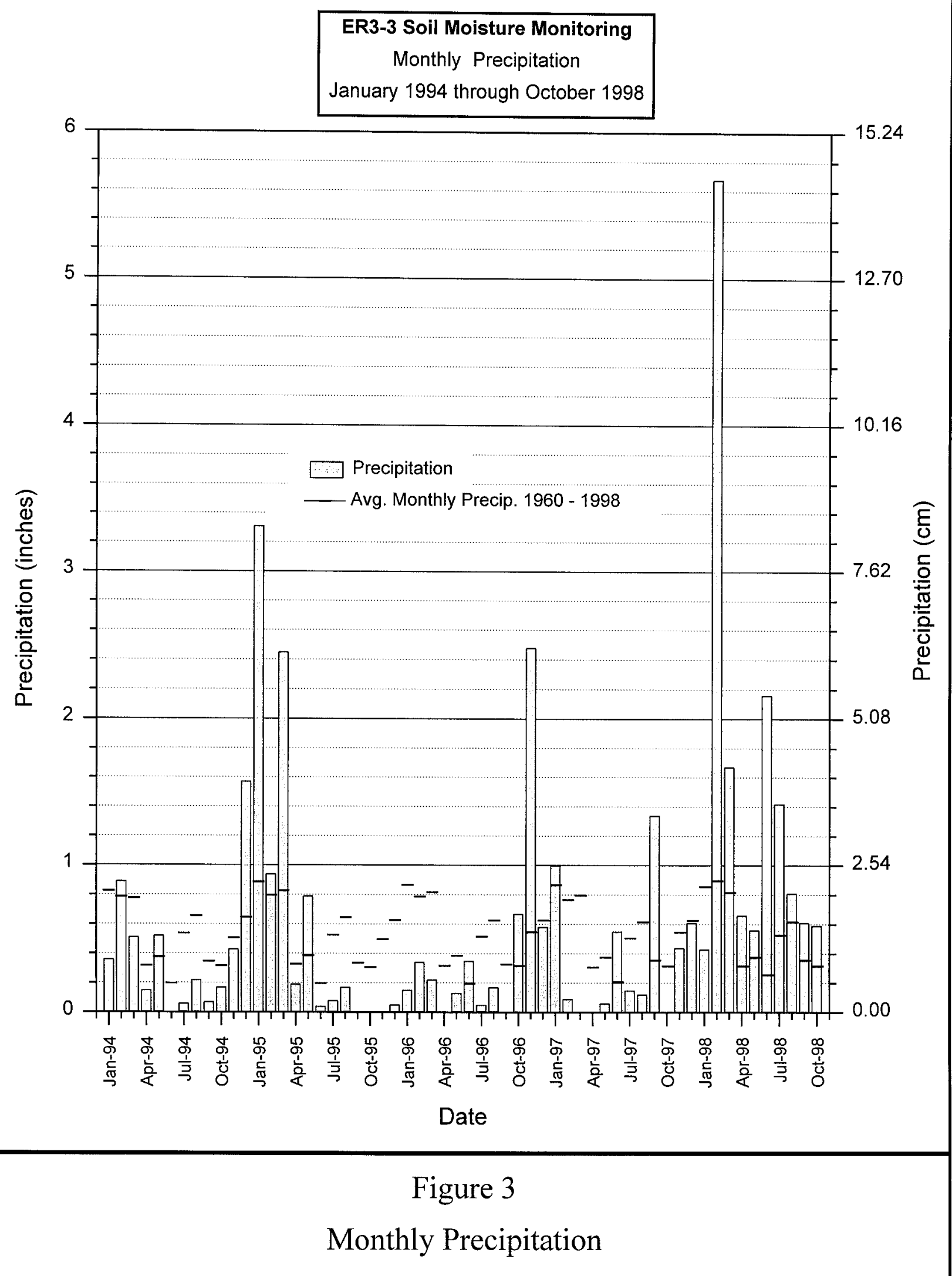


The next four graphs, Baseline Difference (Figures 5 through 8), show the changes occurring for the four 1998 quarterly monitoring periods along the entire length of a neutron access tube relative to baseline conditions. It is calculated by subtracting the baseline (first-year average) neutron count from the current raw neutron count on a depth basis. The result of this subtraction is referred to as the Residual Raw Count. The Residual Raw Count is plotted along with the actual Raw Neutron Counts of both the current and baseline data vs Depth from the top of the casing. A positive residual neutron count indicates conditions at that depth and point in time that are wetter than baseline conditions, while negative values indicate dryer conditions.

Repeatability and instrumentation noise is approximately \pm 100 counts and, as a result, the residual graph has a noisy chaotic character due to the absence of any signal. The Baseline Difference graph provides detailed information on the overall performance of the entire unit, while the Cumulative Residual graph focuses only on cumulative trends relative to the regulatory level of concern at a specific depth and is used to make compliance decisions.

\subsubsection{Discussion of Analytical Data Trends}

The ER3-3 borehole is logged on a quarterly interval occurring in January, April, July, and October.

The Cumulative Residual Neutron Counts Graph (Figure 4) provides summary monitoring information over time with respect to the level of regulatory concern. The baseline data set, as indicated on the graph, was derived from the first ten months of data. Below the Cumulative Residual plot is the monthly cumulative precipitation obtained from the BJY Weather Station.

The Cumulative Residual Neutron Counts (Figure 4) in the regulated interval are plotted on a

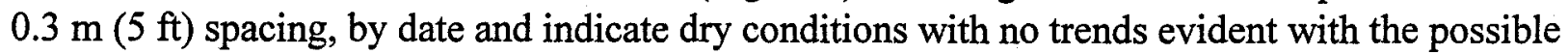
exception at $82.3 \mathrm{~m}(270 \mathrm{ft})$ level where counts remain above 100 in the second and third quarters due to suspected positioning errors of the logging tool.

The moisture content of the regulated interval between 73.2 to $82.3 \mathrm{~m} \mathrm{(240} \mathrm{to} 270 \mathrm{ft}$ ) remains dry, stable, and is below the compliance Action Level of 200 counts.

Performance along the entire neutron access tube is found in the Baseline Difference graphs (Figures 5 through 8). These graphs show the raw neutron counts obtained from both the baseline data set and the current quarterly monitoring period as well as the residual counts (Quarter - Baseline) on a one foot interval. This presentation is useful to determine moisture changes occurring outside of the regulated interval as well as monitoring for subsidence. The 200 count Action Level and the extent of the regulated interval are labeled for reference. 


\subsubsection{January 1998 - First Quarter}

The January 1998 Baseline Difference graph is shown in Figure 5. Borehole conditions are observed to be dry and stable, with no trends or indications of subsidence evident in the data.

The area immediately beneath the cement plug shows an air gap with apparent "drying" which is probably due to the settling of the backfill in this area. The apparent drying trend remains at $17.98 \mathrm{~m}(59 \mathrm{ft})$ in the January and subsequent monitoring quarters and its extent is unchanged from the October 1997 monitoring period.

The moisture content of the regulated interval between 73.2 to $82.3 \mathrm{~m}$ ( 240 to $270 \mathrm{ft}$ ) remains dry and is below the compliance Action Level of 200 counts. Evidence of subsidence is not observed in the data.

\subsubsection{April 1998 - Second Quarter}

The April 1998 Baseline Difference graph is shown in Figure 6. This neutron log indicates dry stable conditions extending from $21 \mathrm{~m}(70 \mathrm{ft})$ to depth with a single point at $72.5 \mathrm{~m}(238 \mathrm{ft})$ lying above the 200 count Action Level at 219 counts. Other smaller single-point anomalies occur indicating both wetting and drying. These points generally occur near changes in lithology (changes in moisture content gradient) and are attributed to positioning errors in these areas. These anomalies can be seen in subsequent logging periods and are probably due to small positioning errors of the neutron probe due to stretching of the logging cable giving a systematic offset. This is a new cable which was purchased in the 1997 monitoring period. Initial tests indicate about $5 \mathrm{~cm}(2 \mathrm{in})$ of error at the mid point of the cable. The cable will be hung and allowed to stretch and then re-calibrated.

The moisture content of the regulated interval between 73.2 to $82.3 \mathrm{~m} \mathrm{(240} \mathrm{to} 270 \mathrm{ft}$ ) remains dry, stable, and is below the compliance Action Level of 200 counts with no indications of subsidence.

\subsubsection{July 1998 - Third Quarter}

The July 1998 Baseline Difference graph is shown in Figure 7. This neutron log also indicates dry stable conditions extending from $21 \mathrm{~m}$ (70 feet) to depth. The same positioning errors noted in the previous quarters can be seen in this quarter. The one point positioning error noted at $72.5 \mathrm{~m}(238 \mathrm{ft})$ in depth in the second quarter is relatively unchanged at 203 counts. Similar single-point anomalies occur at $82.0 \mathrm{~m}(269 \mathrm{ft})$ and $99.7 \mathrm{~m}(327 \mathrm{ft})$.

The moisture content of the regulated interval between 73.2 to $82.3 \mathrm{~m} \mathrm{(240} \mathrm{to} 270 \mathrm{ft}$ ) remains dry, stable, and is below the compliance Action Level of 200 counts with no indications of subsidence. 


\subsubsection{October 1998 - Fourth Quarter}

Figure 8 is the October 1998 Baseline Difference graph. This neutron log also indicates dry stable conditions extending from $21 \mathrm{~m}(70 \mathrm{ft})$ to depth. The positioning errors are still evident near lithology changes in the deeper portions of the borehole.

The moisture content of the regulated interval between 73.2 to $82.3 \mathrm{~m} \mathrm{(240} \mathrm{to} 270 \mathrm{ft}$ ) remains dry, stable, and is below the compliance Action Level of 200 counts with no indications of subsidence. 


\section{ER3-3 Soil Moisture Monitoring}

Cumulative Residual Neutron Counts July 1995 through October 1998
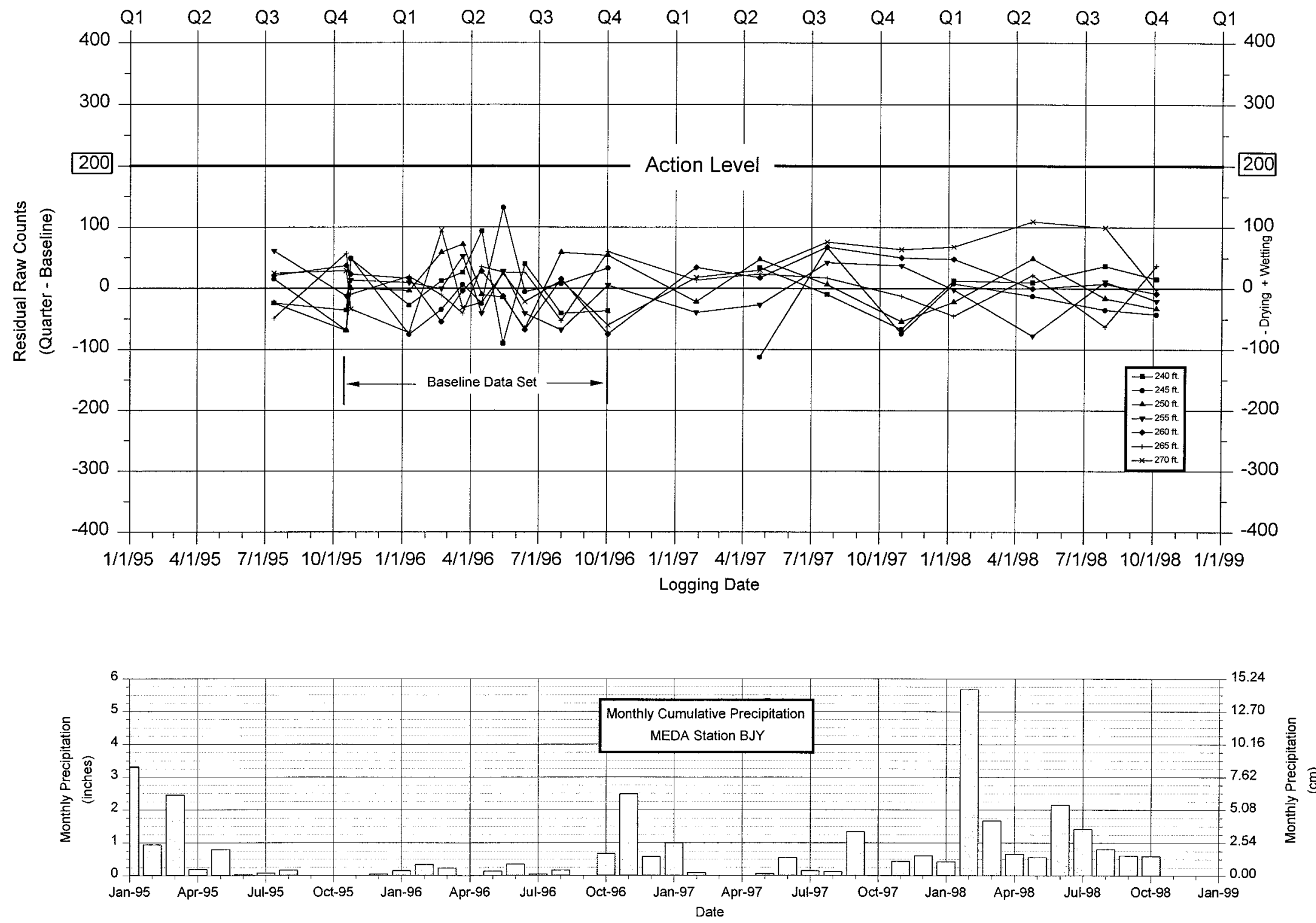


\section{ER3-3 Soil Moisture Monitoring \\ Baseline Difference}

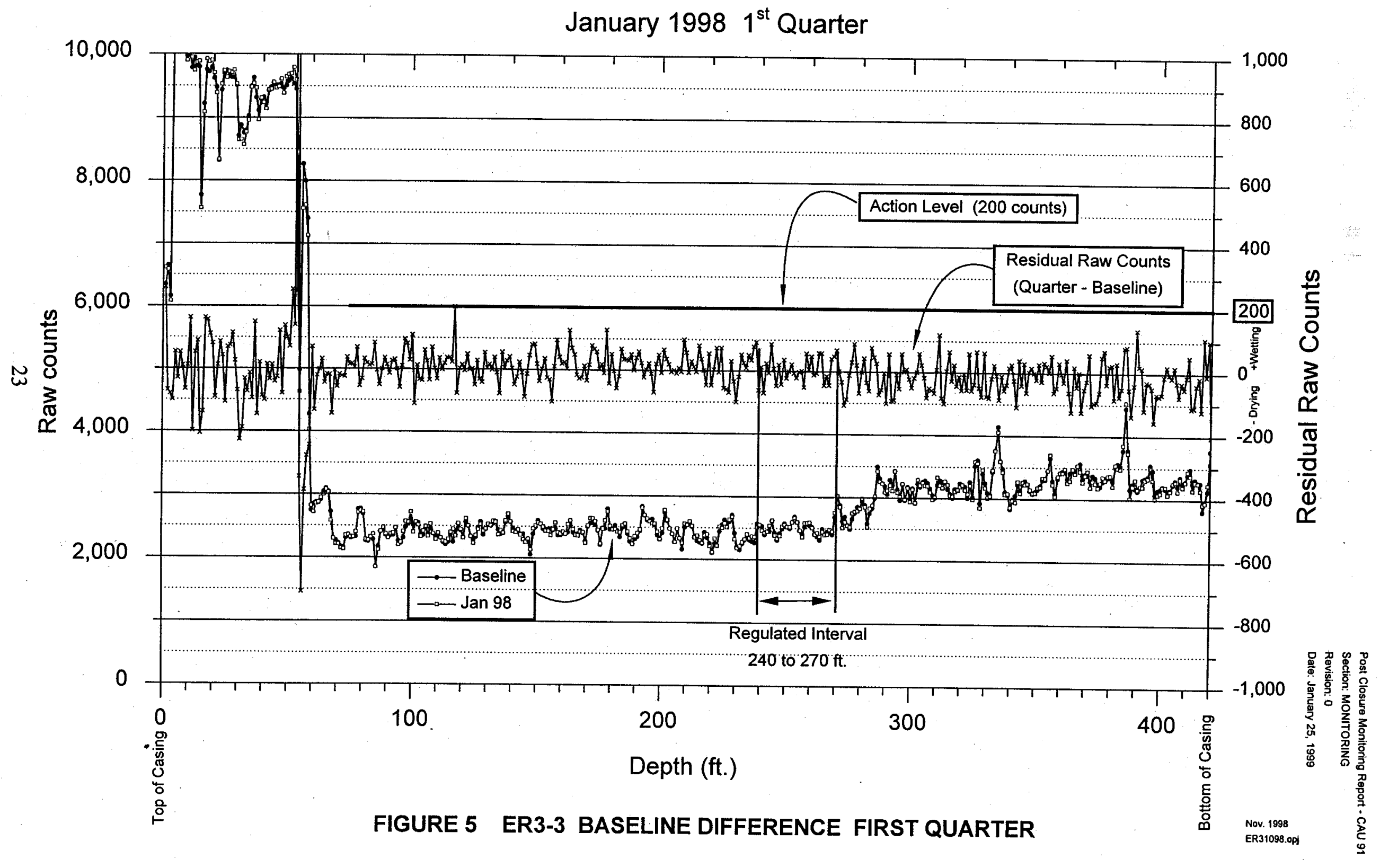




\section{ER3-3 Soil Moisture Monitoring \\ Baseline Difference}

April $19982^{\text {nd }}$ Quarter

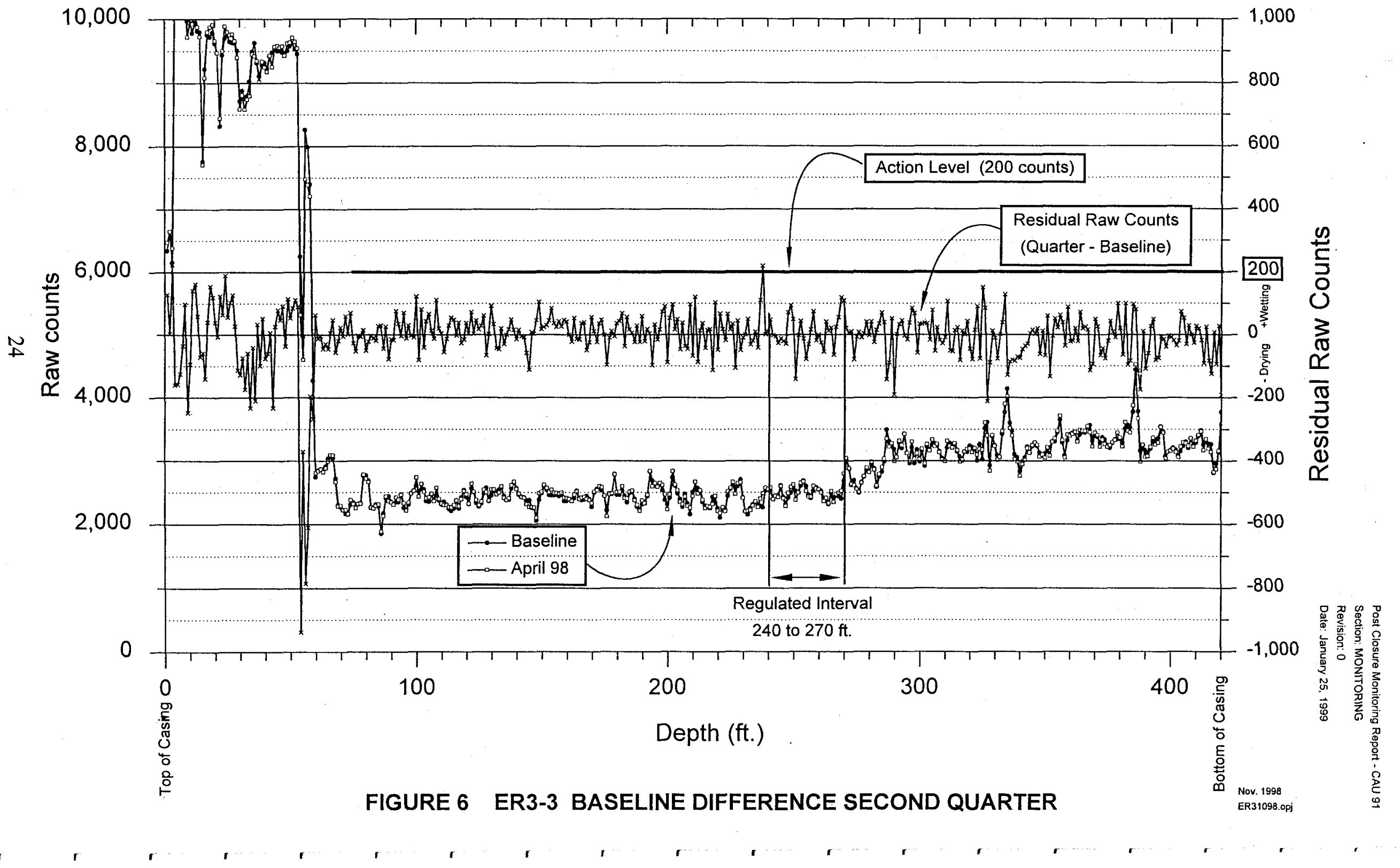




\section{ER3-3 Soil Moisture Monitoring}

Baseline Difference

July $19983^{\text {rd }}$ Quarter

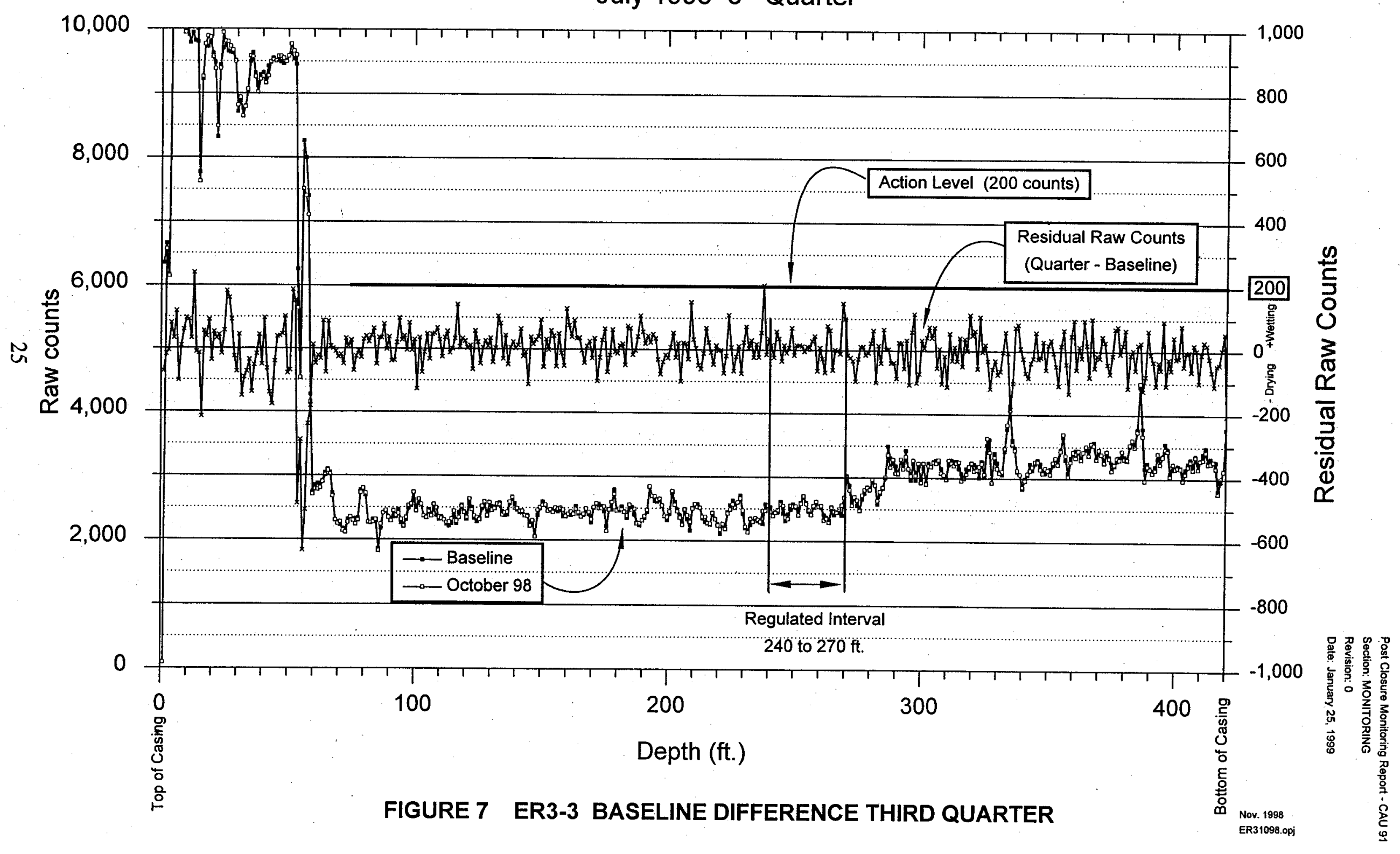




\section{ER3-3 Soil Moisture Monitoring}

Baseline Difference

October $19984^{\text {th }}$ Quarter

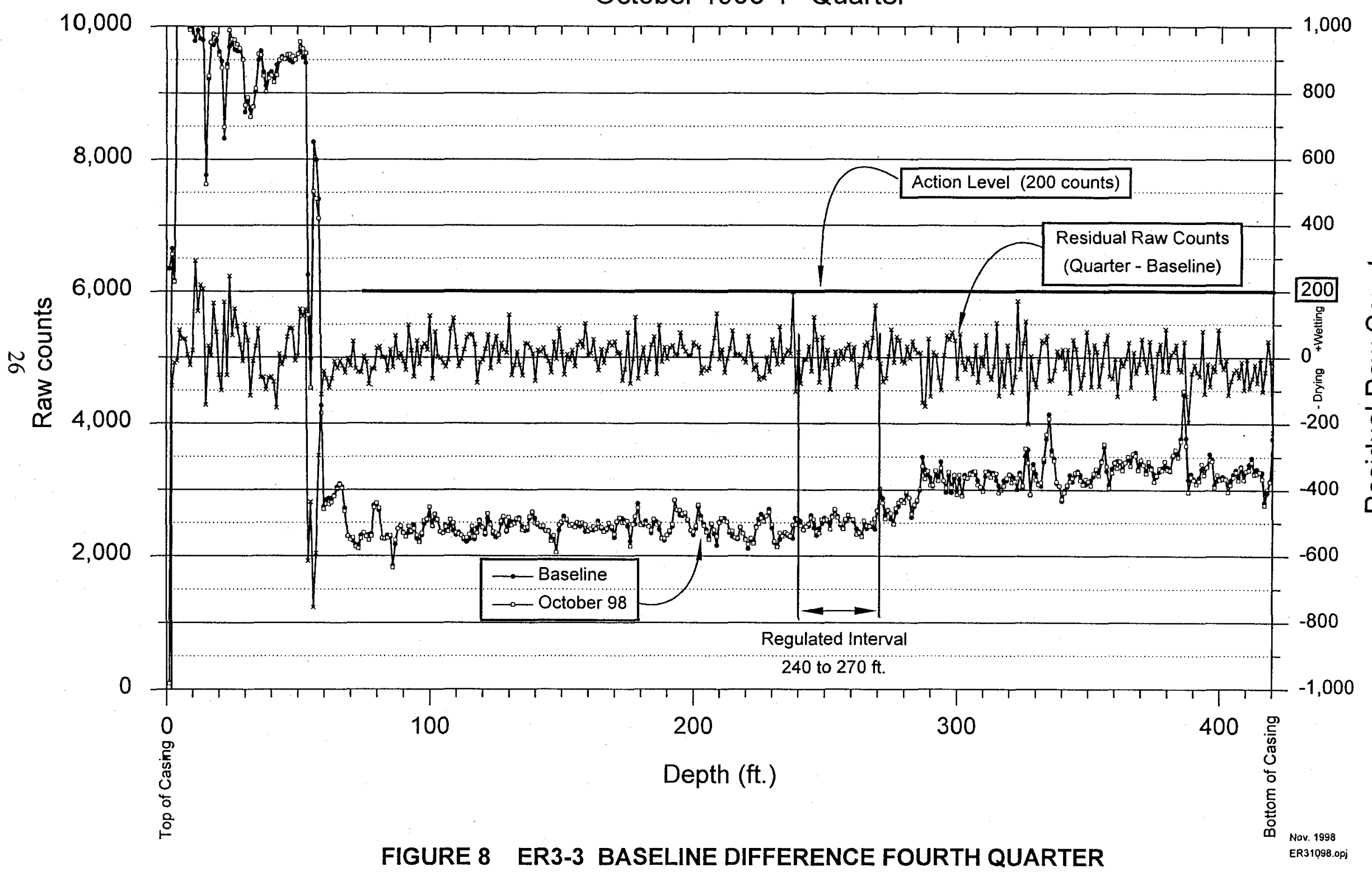




\subsection{SUMMARY, CONCLUSIONS, AND RECOMMENDATIONS}

\subsection{SUMMARY}

- Inspections of the cover were done to identify any significant changes to the unit requiring action. No significant concerns were noted.

- The first baseline subsidence survey was conducted on July 30, 1997. Comparison of the baseline and August 1998 subsidence surveys indicate a $0.884 \mathrm{~cm}(0.029 \mathrm{ft})$ subsidence. A confirmation survey was run in September and indicated a $0.640 \mathrm{~cm}$ $(0.021 \mathrm{ft})$ subsidence. It is not clear if this is due to survey errors or actual subsidence until additional observations are made.

- Visual inspections of the concrete cover indicate no evidence of subsidence.

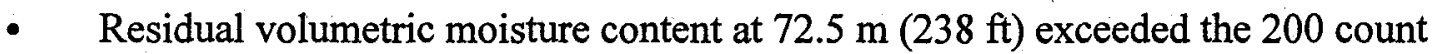
action level in April and July 1998 with a residual moisture count of 219 and 203, respectively. This depth is not in the regulated interval of 73.2 to $82.3 \mathrm{~m} \mathrm{(240} \mathrm{to}$ $270 \mathrm{ft}$ ). These higher counts occur in an area with a significant change in the lithology and can be attributed to positioning errors due to cable stretch or a slightly different length in the new logging cable. The cable will be stretched and the depth markers recalibrated.

- The ER3-3 neutron moisture data obtained in 1998 are below the Action Level of 200 residual raw counts within the regulated interval.

\subsection{CONCLUSIONS}

- No significant concerns were observed during the site inspections over the period October 1997 through October 1998.

- The subsidence survey and visual inspections have detected approximately $0.762 \mathrm{~cm}(0.025 \mathrm{ft})$ subsidence in the closure cap. The measured subsidence may be due to either incremental survey errors or an actual subsidence of the monument. If subsequent surveys indicate no change in subsidence, then this subsidence can be attributed to survey errors in the baseline survey. If a trend is found that continues in future surveys, the result will be due to actual subsidence. 
- The single-point anomalies observed in the deeper portions of the borehole are attributed to small positioning errors probably associated with stretch in the new logging cable.

- Both the Baseline Difference and Cumulative Residual data indicate dry stable conditions for all quarterly monitoring periods. The Residual Raw Neutron Counts remain below the compliance Action Level of 200 counts within the regulated interval for period from October 1997 through October 1998.

- The closure is in compliance and performing as designed.

\subsection{RECOMMENDATIONS}

- Although not within a compliance interval or of regulatory concern, the drying trend observed in the bentonite seal and sloughed soils beneath the cement well head protection plug will continue to be monitored to determine if the trend represents a void or drying trend within this material.

- Future subsidence surveys need to address the question of whether the observed $0.762 \mathrm{~cm}(0.025 \mathrm{ft})$ subsidence is due to survey errors or actual subsidence. Because the apparent subsidence is so small, tight survey control will be needed for future surveys in order to resolve the question.

- In an effort to minimize the number of one-point positioning errors observed in the logs, the logging cable will be suspended with a weight to stretch the cable before recalibrating the depth markers. This calibration of the depth markers should eliminate any systematic offset or cable stretch errors. 


\subsection{REFERENCES}

CPN, 1984, 503DR Hydroprobe Operating Manual, CPN Corporation.

Efron Bradley, et al. 1993, An Introduction to the Bootstrap, Chapman \& Hall.

Nevada Division of Environmental Protection, 1996, letter from P. J. Liebendorfer to S. A. Mellington, Review of Revised Technical Basis for Setting the Action Level for Subsurface Monitoring of ER3-3 (U-3fi Waste Disposal Site CAU \#91 \{Site\}), December 9, 1996.

Nevada Division of Environmental Protection, 1997, Nevada Division of EnvironmentalProtection Permit for a Hazardous Waste Management Facility, Permit Number NEV HW009, May 1997.

Tattro, L. D., Los Alamos National Laboratory, August 4, 1989, Correspondence to Mr. Darrell M. Warren, Las Vegas, NV.

U.S. Department of Energy, 1988, Environmental Survey Preliminary Report. Nevada Test Site, Mercury. Nevada, DOE/EH/OEU-ISP, Washington, D.C.

U.S. Department of Energy, 1995a, Resource Conservation and Recovery Act Industrial Site Environmental Restoration Closure Plan, Area 3 U-3fi Waste Unit, DOE/NV-404, UC-700, Las Vegas, NV.

U.S. Department of Energy, 1995b, Resource Conservation and Recovery Act Industrial Sites Environmental Restoration Post Closure Plan. Area 3 U-3fi Waste Unit, DOE/NV-405, UC-700.

U.S. Department of Energy, 1995c, Performance Assessment for the Area 5 Radioactive Waste Management Site at the Nevada Test Site. Nye County, Nevada. DOE/NV/11432-196.

U.S. Department of Energy, 1996, letter from S. A. Mellington, DOE to P. J. Liebendorfer, NDEP, Submittal of the Technical Basis for Setting the Action Level Criteria for Neutron Access Tube ER3-3. ER3-3 Baseline Data Set and Hydrologic Properties Report (CAU 91), October 22, 1996.

U.S. Department of Energy, 1997, First Annual Report RCRA Post-Closure Monitoring and Inspections for the U-3fi Waste Unit for the Period July 1995 - October 1996, DOE/NV-11718-089, UC-712. 


\subsection{REFERENCES (Continued)}

U.S. National Weather Service Nuclear Support Office, 1998, Meteorological Data for The BJY Station.

Waddell, R. K., 1982, Two-dimensional Steady-state Model of Groundwater Flow, Nevada Test Site and Vicinity, Nevada-California, U.S. Geologic Survey Water-Resources Investigations $82-4085,72 \mathrm{p}$.

Winograd, I. J., W. Thordarson, R. A. Young, 1975, Hydrology of the Nevada Test Site and Vicinity, South Eastern Nevada, United States Department of the Interior, Geological Survey. 
Post Closure Monitoring Report - CAU No. 91 Section: ATTACHMENT A

Revision: 0

Date: January 25, 1999

\section{ATTACHMENT A}

\section{PHOTOGRAPHIC LOG}


THIS PAGE INTENTIONALLY LEFT BLANK 
RESOURCE CONSERVATION AND RECOVERY ACT AREA 3 U-3fi WASTE UNIT POST-CLOSURE SITE INSPECTION PHOTOGRAPHIC LOG

\begin{tabular}{|c|c|l||}
\hline PHOTO & DATE & \\
\hline 1 & $9 / 16 / 1998$ & From U-3fi Waste unit looking North \\
\hline 2 & $9 / 16 / 1998$ & From U-3fi Waste unit looking South \\
\hline 3 & $9 / 16 / 1998$ & From U-3fi Waste unit looking East \\
\hline 4 & $9 / 16 / 1998$ & From U-3fi Waste unit looking West \\
\hline 5 & $9 / 16 / 1998$ & U-3fi Waste unit from the North \\
\hline 6 & $9 / 16 / 1998$ & U-3fi Waste unit from the South \\
\hline 7 & $9 / 16 / 1998$ & U-3fi Waste unit from the East \\
\hline 8 & $9 / 16 / 1998$ & U-3fi Waste unit from the West \\
\hline 9 & $9 / 16 / 1998$ & ER3-3 Monitoring Well from the North \\
\hline 10 & $9 / 16 / 1998$ & ER3-3 Monitoring Well from the South \\
\hline
\end{tabular}




\section{RESOURCE CONSERVATION AND RECOVERY ACT AREA 3 U-3fi WASTE UNIT POST-CLOSURE SITE INSPECTION PHOTOGRAPHIC LOG}

\begin{tabular}{|c|c|l||}
\hline $\begin{array}{c}\text { PHOTO } \\
\text { NUMBER }\end{array}$ & DATE & \\
\hline \hline 1 & $3 / 26 / 1998$ & From U-3fi Waste unit looking North \\
\hline 2 & $3 / 26 / 1998$ & From U-3fi Waste unit looking South \\
\hline 3 & $3 / 26 / 1998$ & From U-3fi Waste unit looking East \\
\hline 4 & $3 / 26 / 1998$ & From U-3fi Waste unit looking West \\
\hline 5 & $3 / 26 / 1998$ & U-3fi Waste unit from the North \\
\hline 6 & $3 / 26 / 1998$ & U-3fi Waste unit from the South \\
\hline 7 & $3 / 26 / 1998$ & U-3fi Waste unit from the East \\
\hline 8 & $3 / 26 / 1998$ & U-3fi Waste unit from the West \\
\hline 9 & $3 / 26 / 1998$ & ER3-3 Monitoring Well from the North \\
\hline 10 & $3 / 26 / 1998$ & ER3-3 Monitoring Well from the South \\
\hline
\end{tabular}


Post Closure Monitoring Report - CAU No. 91 Section: APPENDIX A

Revision: 0

Date: January 25, 1999

\section{APPENDIX A}

\section{POST-CLOSURE INSPECTION CHECKLISTS}


THIS PAGE INTENTIONALLY LEFT BLANK 


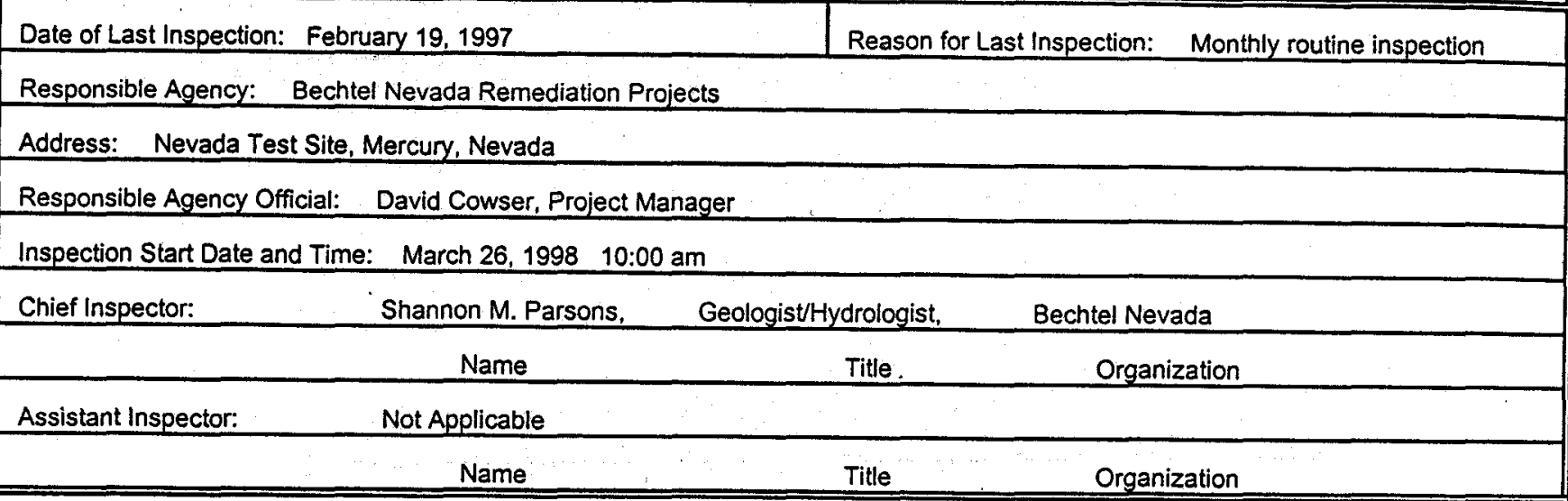

A. GENERAL INSTRUCTIONS

1. All checklist items must be completed and detailed comments made to document the results of the site inspection. The completed checklist is part of the field record of the inspection. Additional pages should be used as necessary to ensure that a complete record is made. Attach the additional pages and number all pages upon completion of the inspection.

2. Inspectors are to provide an up-to-date resume or vitae for inclusion in the inspection report.

3. Any checklist line item marked by an inspector in a SHADED BOX, must be fully explained or an appropriate reference to previous reports provided. The purpose of this requirement is to provide a written explanation of inspector observations and the inspector's rationale for conclusions and recommendations. Explanations are to be placed on additional attachments and crossreferenced appropriately. Explanations, in addition to narrative, will take the form of sketches, measurements, annotated site maps.

4. The site inspection is a walking inspection of the entire site (i.e., the area within 1,000 feet of U-3fi and ER-3-3), including the perimeter and sufficient transects to be able to inspect the entire surface and all features specifically described in this checklist. Every monument, site marker, sign, monitoring well access, and erosion control marker will be inspected.

5. A standard set of color $35 \mathrm{~mm}$ photographs is required. For this site, the standard set consists of 10 photographs (see instructions in Section D.6 of this checklist). In addition, all anomalous features or new features (such as changes in adjacent area land use) are to be photographed. A photo log entry will be made for each photograph taken.

6. Field notes taken to assist in completion of this checklist will become part of the inspection record. No form is specified for field notes, however, they must be legible and in sufficient detail to enable review by succeeding inspectors and the responsible agency.

\begin{tabular}{|c|c|c|c|}
\hline B. PREPARATION (TO be completed prior to site visit) & YES & No & EXPLANATION \\
\hline 1. Post-Closure Permit reviewed. & $\checkmark$ & & . \\
\hline 2. Design basis documents reviewed. & $\nu$ & the & \\
\hline 3. Site as-built plans and site base map reviewed. & $\boldsymbol{\nu}$ & mo & \\
\hline \multirow{3}{*}{$\begin{array}{l}\text { 4. Previous inspection reports reviewed. } \\
\text { a. Were anomalies or trends detected on previous inspections? } \\
\text { b. Was maintenance performed? }\end{array}$} & $\checkmark$ & & . \\
\hline & & $\checkmark$ & \\
\hline & 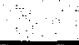 & 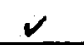 & \\
\hline \multirow{3}{*}{$\begin{array}{l}\text { 5. Site maintenance and repair records reviewed. } \\
\text { a. Has site repair resulted in a change from as-built conditions? } \\
\text { b. Are revised as-builts available that reflect repair changes? }\end{array}$} & $\checkmark$ & in & . \\
\hline & & $\checkmark$ & \\
\hline & & $\sim$ & Not applicable. \\
\hline \multirow[t]{3}{*}{$\begin{array}{l}\text { 6. Aerial photos, if taken since last inspection, reviewed. For each } \\
\text { set, enter the date, scale, and if interpreted. }\end{array}$} & & $\checkmark$ & $\begin{array}{l}\text { Aerial photographs are not routinely } \\
\text { taken at the NTS. }\end{array}$ \\
\hline & & $\checkmark$ & \\
\hline & & $\checkmark$ & \\
\hline
\end{tabular}

7. Were any of the following suggested by examination of the aerial photographs? (If yes, give photo set date).

a. Intrusion by man? available 


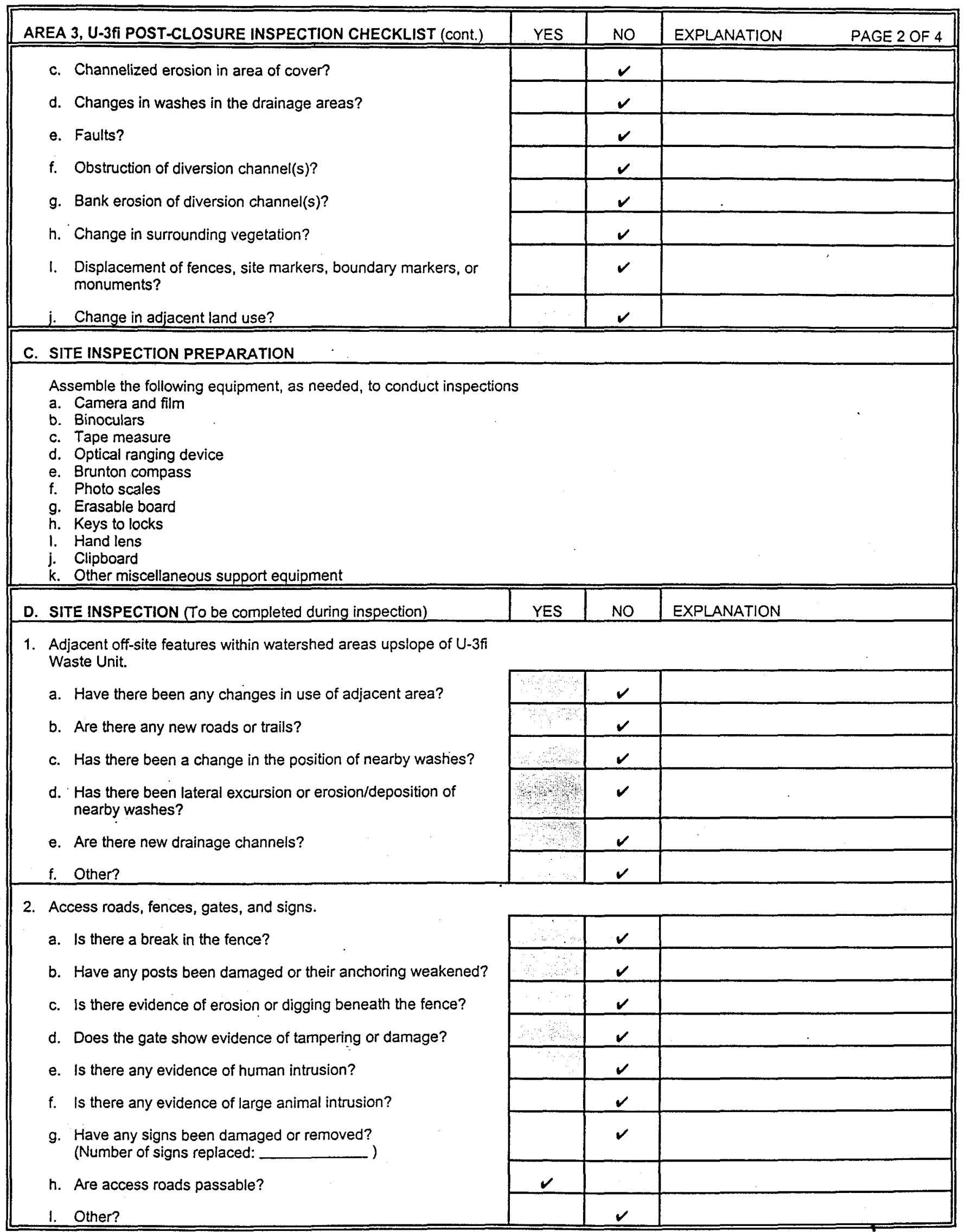




\begin{tabular}{||l|l|l|l|l|l|}
\hline AREA 3, U-3fi POST-CLOSURE INSPECTION CHECKLIST (cont.) & YES & NO & EXPLANATION \\
\hline
\end{tabular}

3. Monuments and other permanent features

a. Have the survey or boundary monuments been defaced or disturbed?

b. Have the site markers been disturbed by man or natural processes?

c. Do natural processes threaten to integrity of any monument or site marker?

d. Other?

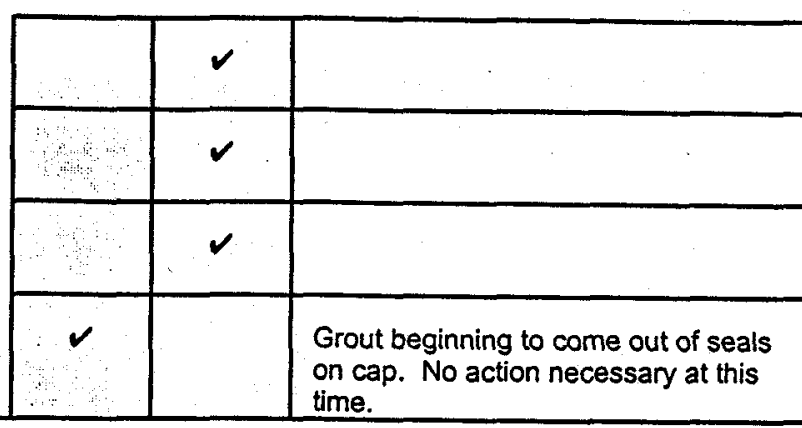

4. U-3fi Waste Unit cover

a. Is there evidence of settling?

b. Is there cracking?

c. Is there evidence of erosion around the cap (wind or water)?

d. Is there evidence of animal burrowing?

e. Other?

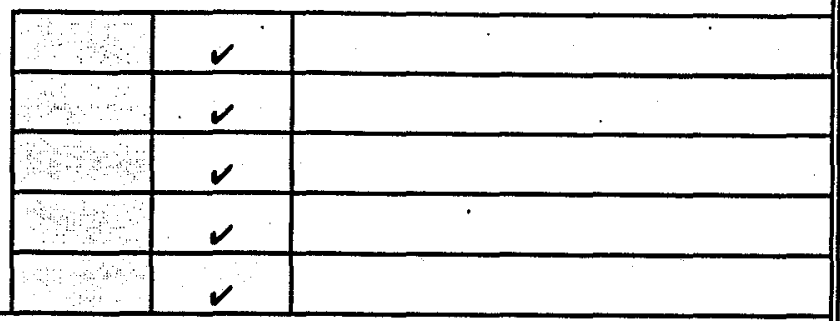

5. Site drainage features (within 1,000 feet of $U-3 f i$ ).

a. Is the drainage as describe in the site plans?

b. Is there evidence of bank erosion?

c. Is there evidence of channel erosion?

d. Is there evidence of sedimentation?

e. Is there channel obstruction?

f. Is there any evidence that diversion channels (if present) are not performing their function?

g. Other?

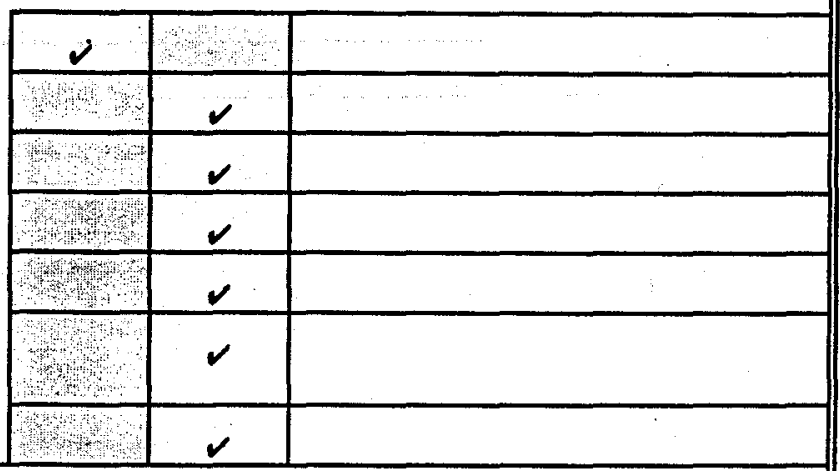

6. Photo Instructions

A total of 10 photographs are required to be taken during each inspection of the Area 3 U-3fi Waste Unit. Additional photos may also be taken. The required photographs shall be taken as follows:

- Four (4) from the center of the U-3fi Waste Unit cap, one in each compass direction (i.e., N, S, E, W).

- Four (4) of the U-3fi Waste Unit cap, one from each compass direction,

- Two (2) of the ER-3-3 monitoring well surface completion with compass directions noted on the photo log.

7. Photo Documentation

a. Have all photos required by the photo instructions been taken? (see last page of checklist)

b. Has a photo log been prepared for each roll of film exposed?

c. Number of rolls exposed (_ـ 10 photos taken $)$

d. Other?

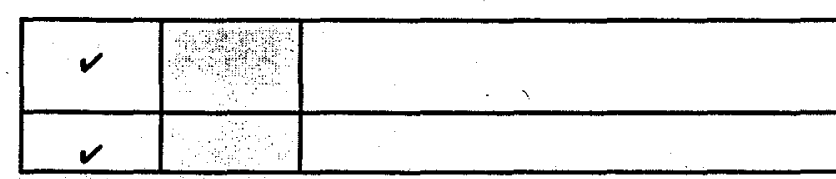

Monitoring well ER-3-3 access

a. Has the monitoring well access been disturbed by man or natural processes?

b. Does any natural process threaten the integrity of the monitoring well access?

c. Is the monitoring well access label plate intact and legible?

d. Is the monitoring well access capped and properly secured?

e. Other?

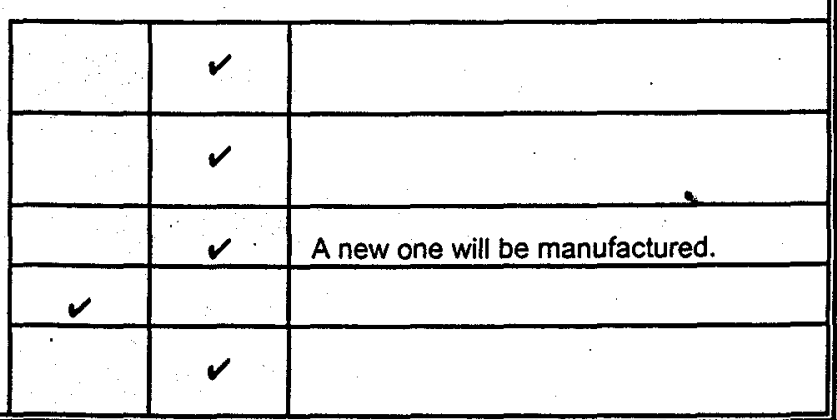




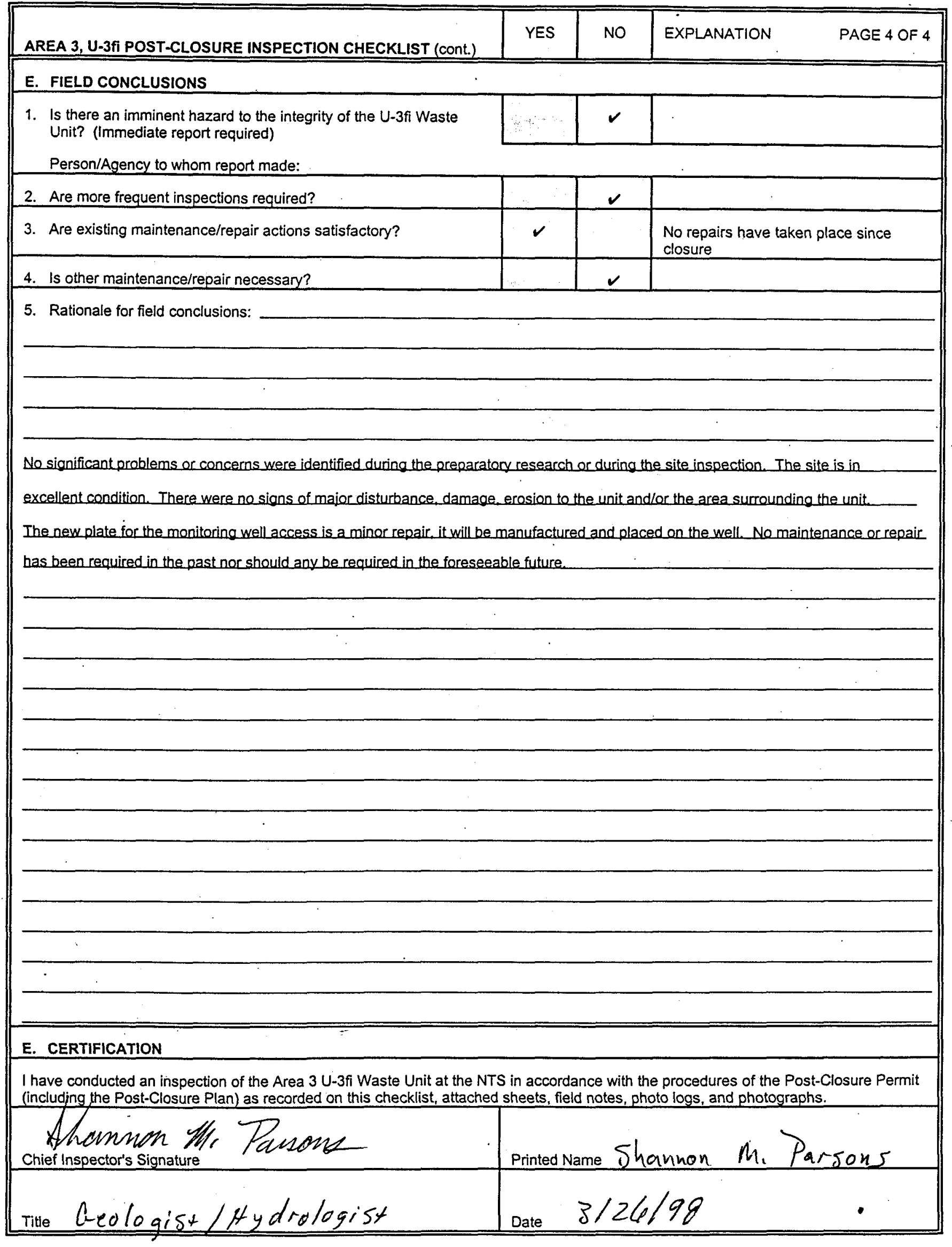


Date of Last Inspection: August 19, 1998

Reason for Last Inspection: Monthly routine inspection

Responsible Agency: Bechtel Nevada Environmental Restoration

Address: Nevada Test Site, Mercury, Nevada

Responsible Agency Official: David Cowser, Project Manager

Inspection Start Date and Time: September 16, $1998 \quad 3: 00 \mathrm{pm}$

Chief Inspector: $\quad$ Shannon M. Parsons-DePry, _____ Geologist/Hydrologist, $\quad$ Bechtel Nevada

\begin{tabular}{|c|c|c|c|}
\hline & Name & Title & Organization \\
\hline Assistant Inspector: & Not Applicable & & \\
\hline & Name & Title & Organization \\
\hline
\end{tabular}

A. GENERAL INSTRUCTIONS

1. All checklist items must be completed and detailed comments made to document the results of the site inspection. The completed checklist is part of the field record of the inspection. Additional pages should be used as necessary: to ensure that a complete record is made. Attach the additional pages and number all pages upon completion of the inspection.

2. Inspectors are to provide an up-to-date resume or vitae for inclusion in the inspection report.

3. Any checklist line item marked by an inspector in a SHADED BOX, must be fully explained or an appropriate reference to previous reports provided. The purpose of this requirement is to provide a written explanation of inspector observations and the inspector's rationale for conclusions and recommendations. Explanations are to be placed on additional attachments and crossreferenced appropriately. Explanations, in addition to narrative, will take the form of sketches, measurements, annotated site maps.

4. The site inspection is a walking inspection of the entire site (i.e., the area within 1,000 feet of U-3fi and ER-3-3), including the perimeter and sufficient transects to be able to inspect the entire surface and all features specifically described in this checklist. Every monument, site marker, sign, monitoring well access, and erosion control marker will be inspected.

5. A standard set of color $35 \mathrm{~mm}$ photographs is required. For this site, the standard set consists of 10 photographs (see instructions in Section D. 6 of this checklist). In addition, all anomalous features or new features (such as changes in adjacent area land use) are to be photographed. A photo log entry will be made for each photograph taken.

6. Field notes taken to assist in completion of this checklist will become part of the inspection record. No form is specified for field notes, however, they must be legible and in sufficient detail to enable review by succeeding inspectors and the responsible. agency.

B. PREPARATION (To be completed prior to site visit)

1. Post-Closure Permit reviewed.

2. Design basis documents reviewed.

3. Site as-built plans and site base map reviewed.

4. Previous inspection reports reviewed.

a. Were anomalies or trends detected on previous inspections?

b. Was maintenance performed?

5. Site maintenance and repair records reviewed.

a. Has site repair resulted in a change from as-built conditions?

b. Are revised as-builts available that reflect repair changes?

6. Aerial photos, if taken since last inspection, reviewed. For each set, enter the date, scale, and if interpreted.
a. Date: Aug/Sept 1994
b. Scale: $1^{\prime \prime}=2000^{\prime}$
a. Date:
b. Scale:

Not applicable.

\begin{tabular}{|c|r|l|}
\hline YES & NO & EXPLANATION \\
\hline$\checkmark$ & & \\
\hline$\checkmark$ & & \\
\hline$\checkmark$ & & \\
\hline & $\checkmark$ & \\
\hline$\checkmark$ & $\checkmark$ & \\
\hline & $\checkmark$ & \\
\hline & $\checkmark$ & Not applicable. \\
\hline & $\checkmark$ & Aerial photographs are not routinely \\
& & taken at the NTS. \\
\hline & $\checkmark$ & \\
\hline & $\checkmark$ & \\
\hline
\end{tabular}

7. Were any of the following suggested by examination of the aerial photographs? (If yes, give photo set date).

a. Intrusion by man?

b. Intrusion by animals?

\begin{tabular}{|c|c|l|}
\hline & $\checkmark$ & $\begin{array}{l}\text { Not applicable- no aerial photographs } \\
\text { available }\end{array}$ \\
\hline & $\checkmark$ & Not applicable \\
\hline
\end{tabular}




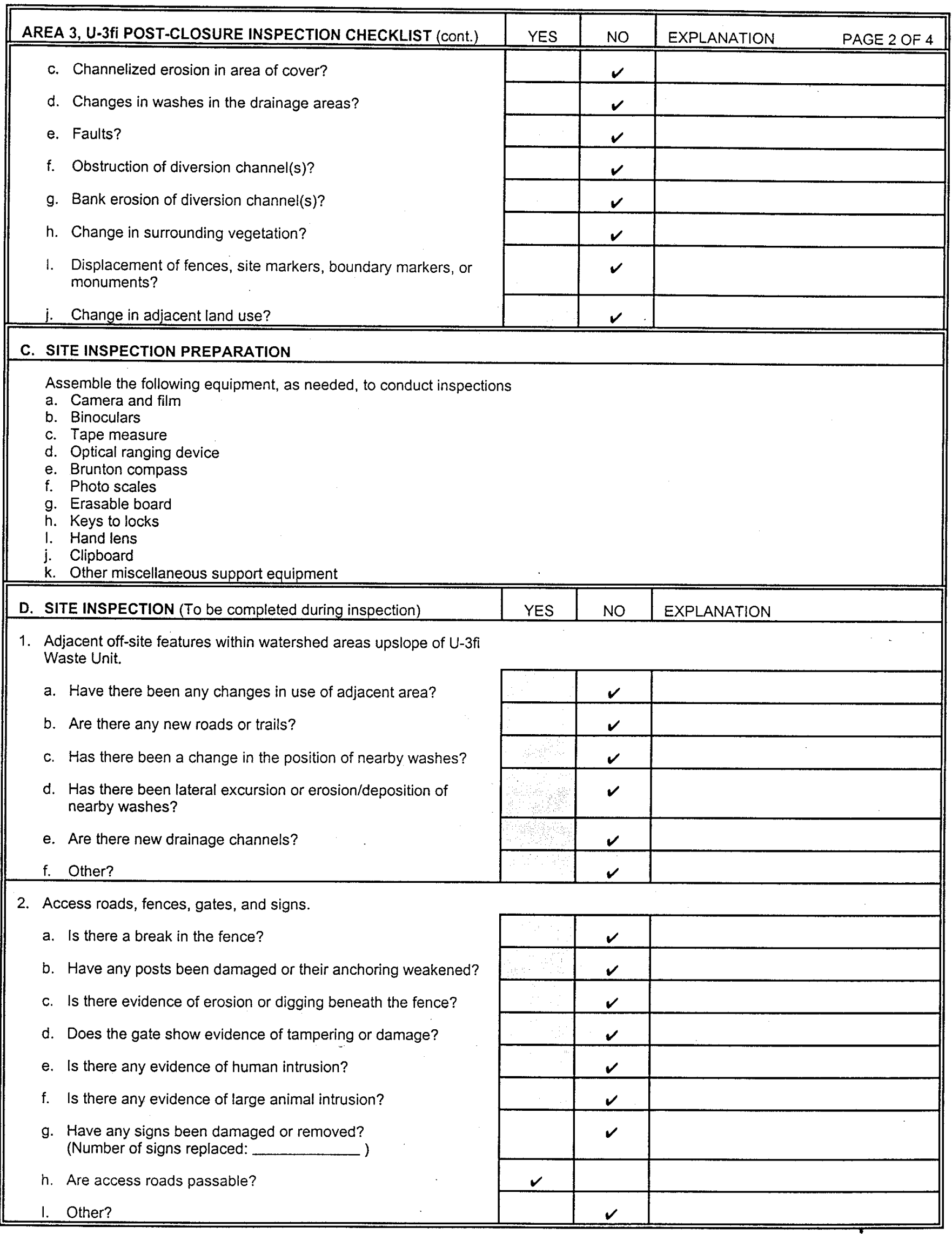




\begin{tabular}{|l|l|l|l|l|}
\hline AREA 3, U-3fi POST-CLOSURE INSPECTION CHECKLIST (cont.) & YES & NO & EXPLANATION \\
\hline
\end{tabular}

3. Monuments and other permanent features

a. Have the survey or boundary monuments been defaced or disturbed?

b. Have the site markers been disturbed by man or natural processes?

c. Do natural processes threaten to integrity of any monument or site marker?

d. Other?

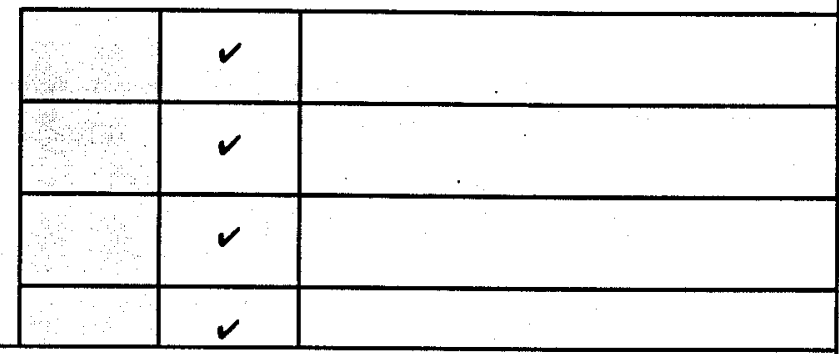

4. U-3fi Waste Unit cover
a. Is there evidence of settling?
b: Is there cracking?
c. Is there evidence of erosion around the cap (wind or water)?
d. Is there evidence of animal burrowing?
e. Other?

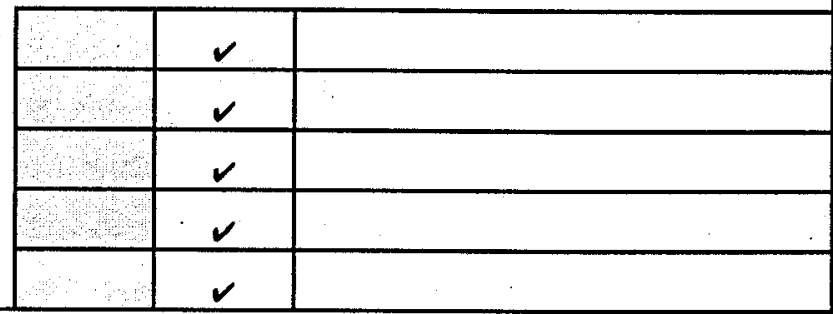

5. Site drainage features (within 1,000 feet of $U-3 f i$ ).

a. Is the drainage as describe in the site plans?

b. Is there evidence of bank erosion?

c. Is there evidence of channel erosion?

d. Is there evidence of sedimentation?

e. Is there channel obstruction?

f. Is there any evidence that diversion channels (if present) are not performing their function?

g. Other?

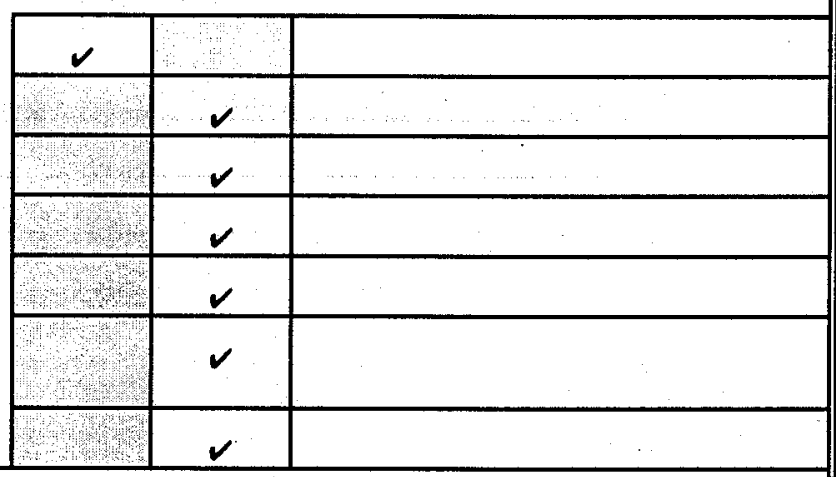

6. Photo Instructions

A total of 10 photographs are required to be taken during each inspection of the Area 3 U-3fi Waste Unit. Additional photos may also be taken. The required photographs shall be taken as follows:

- Four (4) from the center of the U-3fi Waste Unit cap, one in each compass direction (i.e., N, S, E, W),

- Four (4) of the U-3fi Waste Unit cap, one from each compass direction,

- Two (2) of the ER-3-3 monitoring well surface completion with compass directions noted on the photo log.

7. Photo Documentation

a. Have all photos required by the photo instructions been taken? (see last page of checklist)

b. Has a photo log been prepared for each roll of film exposed?

c. Number of rolls exposed (_ 10 photos taken $)$

d. Other?

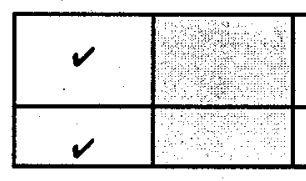

Monitoring well ER-3-3 access

a. Has the monitoring well access been disturbed by man or natural processes?

b. Does any natural process threaten the integrity of the monitoring well access?

c. Is the monitoring well access label plate intact and legible?

d. Is the monitoring well access capped and properly secured?

e. Other?

\begin{tabular}{|r|r|l|}
\hline & $\checkmark$ & \\
\hline & $\checkmark$ & \\
\hline$\checkmark$ & & \\
\hline$\checkmark$ & & \\
\hline & $\checkmark$ & \\
\hline
\end{tabular}




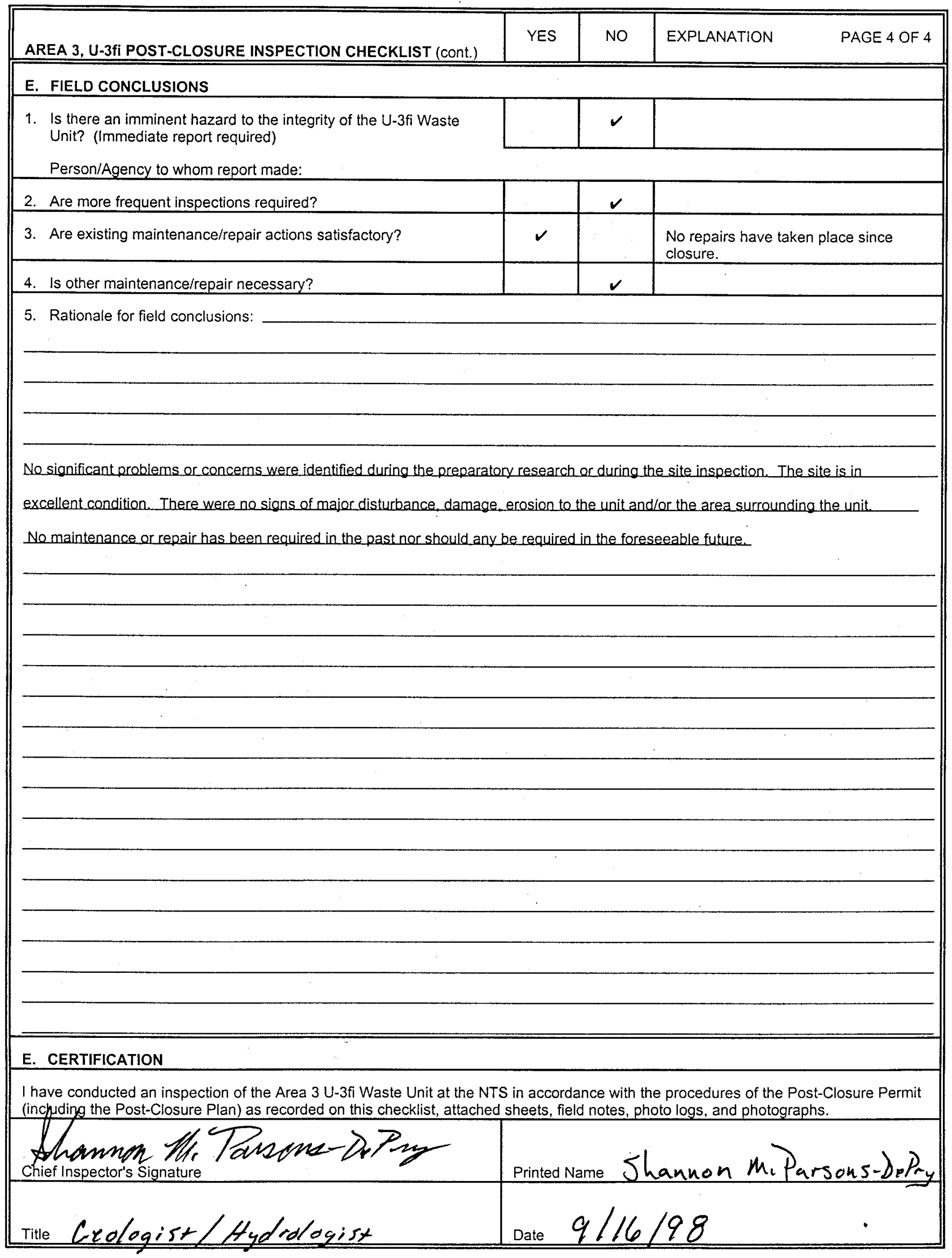


Post Closure Monitoring Report - CAU No. 91 Section: APPENDIX B

Revision: 0

Date: January 25, 1999

\section{APPENDIX B}

\section{SUBSIDENCE SURVEY PLAT}


THIS PAGE INTENTIONALLY LEFT BLANK 

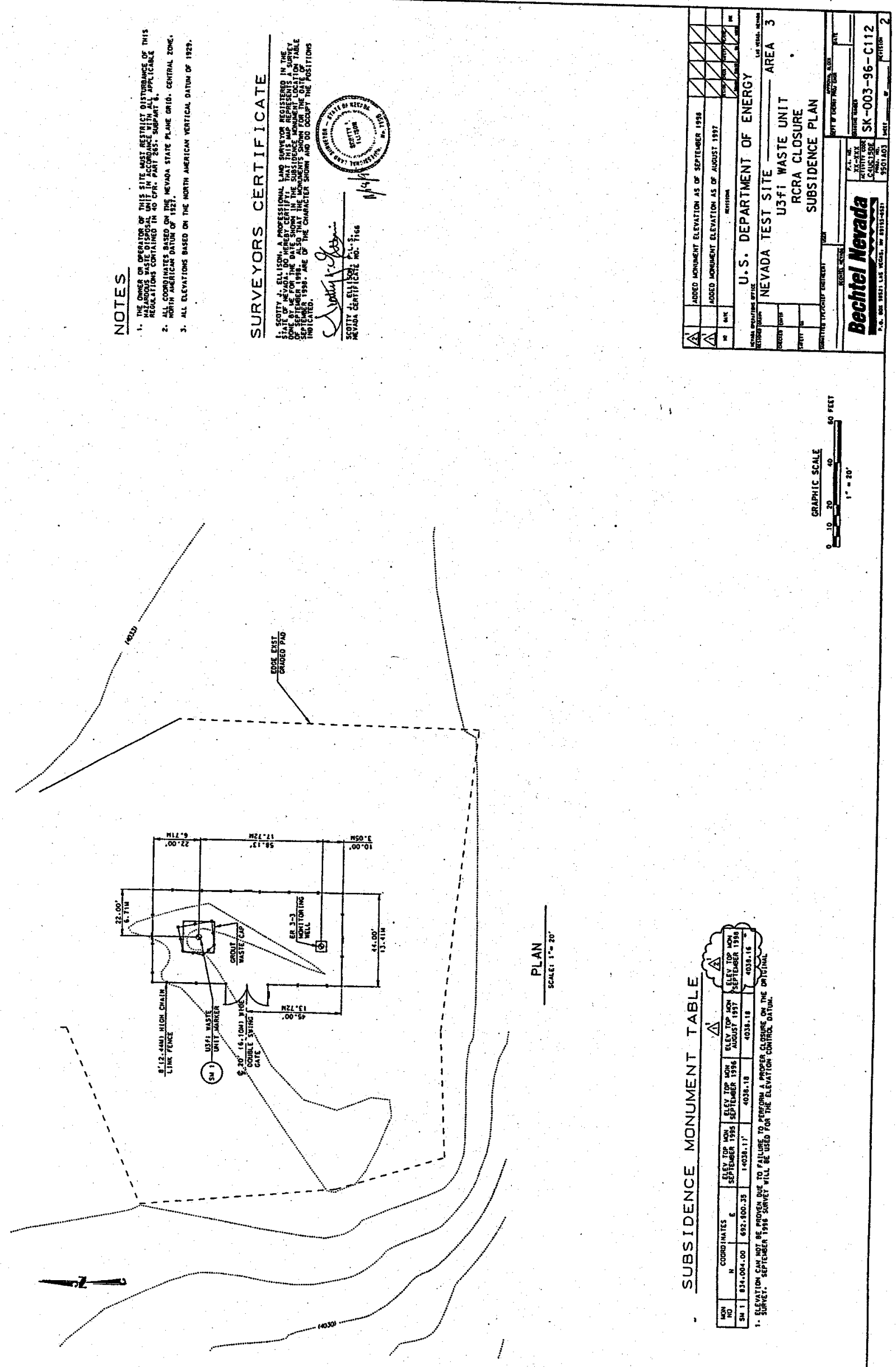
Post Closure Monitoring Report - CAU Section: APPENDIX C

Revision: 0

Date: January 25, 1999

\section{APPENDIX C}

\section{PRECIPITATION RECORDS}


October 1997

\begin{tabular}{|l|l|l|l|l|l|l|l|l|l|l|l|l|l|l|l|l} 
A12 & BJY & CS & DAF & DRA & E TU & 4JA & 40 Mi & LF2 & MER & MV & PM1 & PHS & RV & TS2 & W5B & UCC \\
\hline
\end{tabular}

$\frac{\frac{1}{2}}{\frac{3}{5}}$

12

13

14

15

16

17

18

18

20

22

23

24

25

26

27

28

28

30

31

\begin{tabular}{l|l|l|l|l|l|l|l|l|l|l|l|l|l|l|l|l|l}
\hline OTAL & 0.04 & 0.00 & 0.00 & 0.00 & 0.00 & 0.04 & 0.03 & 0.05 & 0.00 & 0.04 & 0.07 & 0.14 & 0.04 & 0.00 & 0.03 & 0.04 & 0.00 \\
\hline
\end{tabular}

rea 12 Dip Stick Rain Gage Reading:

$0.00^{n}$ from 10/02/97 thru 11/04/97

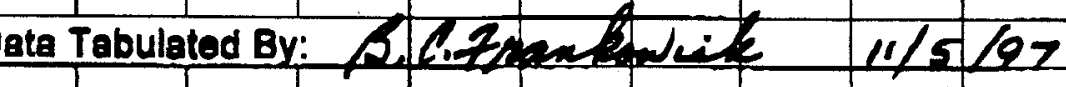

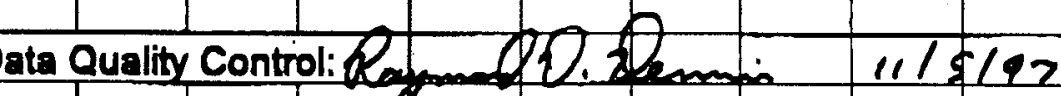
entifled By: 
NTS PRECIPITATION

Decermber 1997

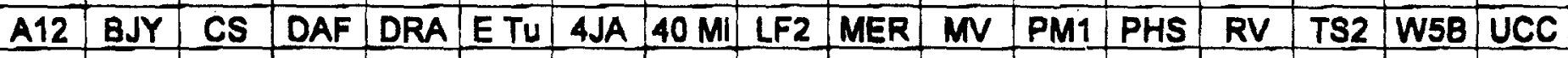

1

2

3

4

\begin{tabular}{l|l|l|}
\hline 5 & 0.62 & 0.07 \\
\hline
\end{tabular}

\begin{tabular}{l|l|l|l|}
\hline 0.68 & 0.03 & 0.18 & 0.37 \\
\hline
\end{tabular}

0.390 .14

\begin{tabular}{l|l|l|l|l|l|l|l|l|l|l|l|}
\hline 6 & 0.45 & 0.35 & 0.39 & 0.10 & 0.23 & 0.45 & 0.57 & 0.66 & 0.47 & 0.26 & 0.70 \\
\hline
\end{tabular}

\begin{tabular}{l|l|l|l|}
\hline 7 & 0.45 & 0.19 \\
\hline
\end{tabular}

0.10

\begin{tabular}{|l|l|l|l|l|l|l|}
0.17 & 0.08 & 0.37 & 0.09 & 0.38 & 0.23 \\
\hline
\end{tabular}

\begin{tabular}{|l|l|l|l|l|}
\hline 0.02 & 0.05 & 0.03 & 0.05 & 0.05 \\
\hline
\end{tabular}

\begin{tabular}{l|l|l|l|l}
0.10 & 0.37 \\
\hline
\end{tabular}

0.100 .46

\begin{tabular}{|l|l|l|l|}
\hline & & 0.02 \\
\hline
\end{tabular}

$\frac{8}{8}$

10

11

12

13

14

15

16

17

18

18

20

21

22

23

24

25

26

27

28

29

30

31

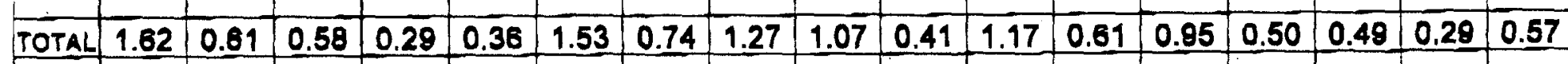

Area 12 Dip Stick Rain Gage Reading:

1.08 inches $12 / 02 / 97$ thru $01 / 08 / 98$

Data Tabulated By:

Data Quallity Control:

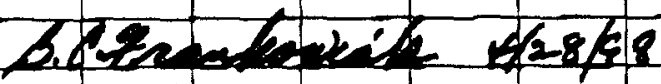

Certified By:

Ronme 0. Demic V/uster 
Januery 1998

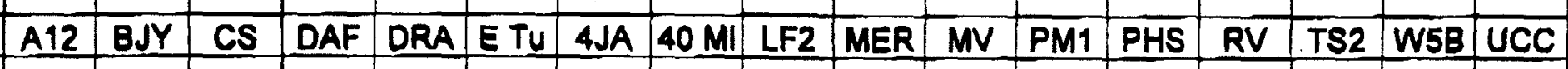

$\frac{1}{2}$

\begin{tabular}{|l|l|l|l|l|l|l|l|l|l|l|l|l|l|l|l|l|l|}
\hline 4 & 0.21 & 0.03 & 0.14 & 0.04 & 0.14 & 0.20 & 0.03 & 0.15 & 0.07 & 0.12 & 0.15 & 0.22 & 0.10 & 0.25 & 0.02 & 0.10 & 0.15 \\
\hline 5 & 0.03 & & & 0.02 & & 0.02 & & 0.06 & 0.03 & & 0.04 & 0.02 & 0.01 & 0.02 & 0.05 & & 0.02 \\
\hline
\end{tabular}

$\frac{6}{7}$

$\frac{1}{8}$

1

\begin{tabular}{l|l|l|l|}
\hline 9 & 0.05 & 0.15 & 0.08 \\
\hline
\end{tabular}

\begin{tabular}{l|l|l|l|}
\hline 10 & 0.12 & 0.05 & 0.14 \\
\hline
\end{tabular}

\begin{tabular}{l|l}
11 & 0.05 \\
\hline 12 & 0.10 \\
\hline
\end{tabular}

$\frac{12}{13}$

14

15

16

17

18

18

20

21

22

23

24

25

26

27

28

$\frac{28}{31}$

\begin{tabular}{|l|l|l|l|l|l|l|l|l|l|l|l|l|l|l|l|l|}
\hline 0.15 & 0.15 & 0.07 & 0.29 & 0.07 & 0.23 & 0.18 & 0.06 & 0.13 & 0.13 & 0.10 & 0.20 & 0.22 & 0.07 & 0.28 & 0.05 & 0.26 \\
\hline
\end{tabular}

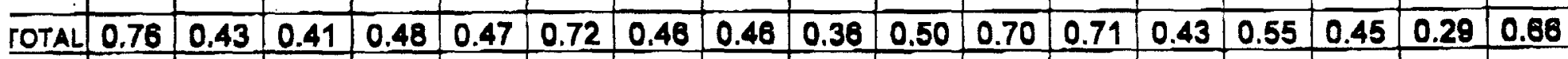

\begin{tabular}{l|l|l}
\hline Area 12 Dip Stick Rain Gage Reading: & .70 Inches & $01 / 00 / 98$ thru $02 / 02 / 98$ \\
\hline
\end{tabular}

Data Tabulated By:

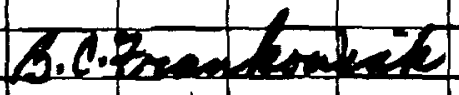

$429 \sqrt{9}$

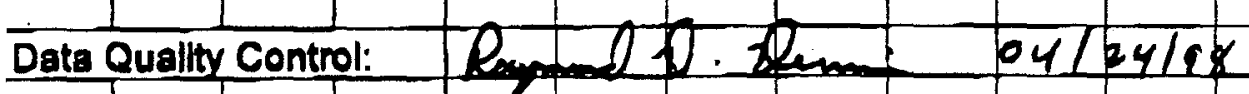

Certifiled By:

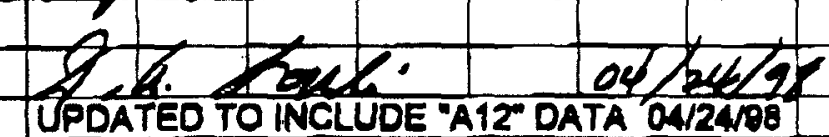




\section{Fobruary 1998}

\begin{tabular}{l|l|l|l|l|l|l|l|l|l|l|l|l|l|l|l|l|} 
A12 & BJY & CS & DAF & DRA & E TU & 4JA & 40 MII LF2 & MER & MV & PM1 & PHS & RV & TS2 & W6B & UCC \\
\hline
\end{tabular}

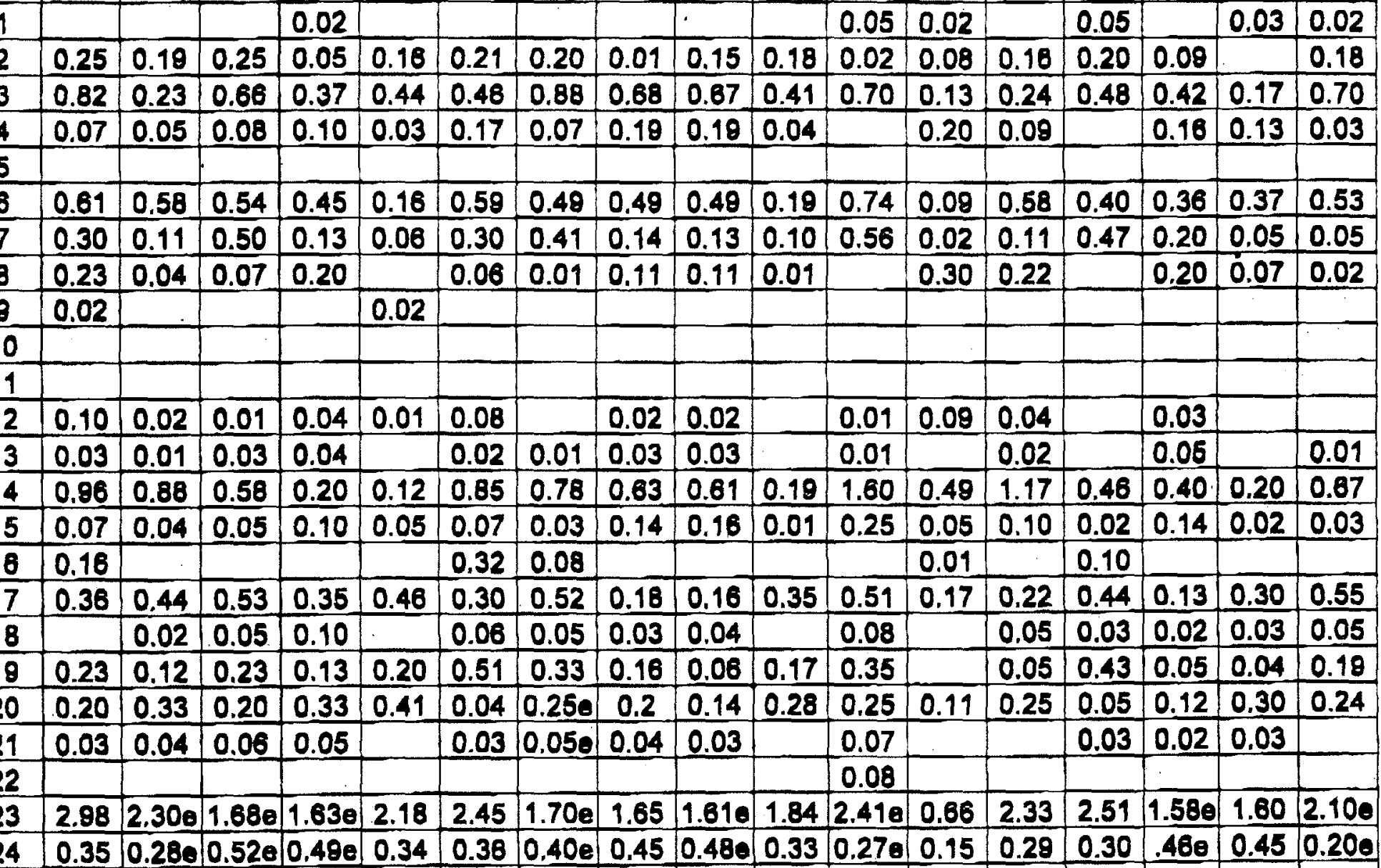

$\frac{25}{28}$

26

27

28

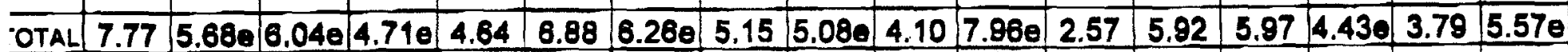

- Eetimated values.

\begin{tabular}{ll|l}
\hline Area 12 Dlp Stick Rain Gape Rogding: & 8.10 Inctie日 $02 / 02 / 98$ thru 03/02/98 \\
\hline
\end{tabular}

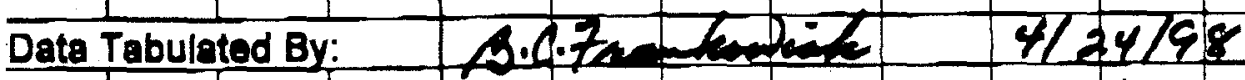

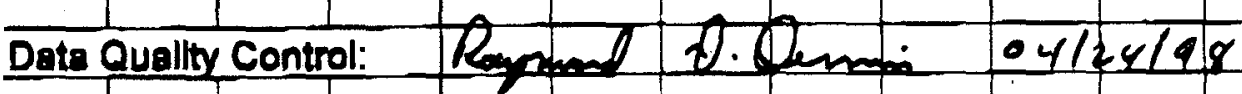


NTS PRECIPITATION

June 1998

\begin{tabular}{l|l|l|l|l|l|l|l|l|l|l|l|l|l|l|l|l|} 
A12 & BJY & CS & DAF & DRA & E TU & 4JA & 40 MI & LF2 & MER & MV & PM1 & PHS & RV & TS2 & W5B & UCC \\
\hline
\end{tabular}

$\frac{1}{2}$

30.55

4

5

6

7

\begin{tabular}{l|l|l|l|l|l}
0.14 & 0.03 \\
\hline
\end{tabular}

0.02

\begin{tabular}{|l|l|l|}
0.14 & 0.02 & 0.14 \\
\hline
\end{tabular}

\begin{tabular}{|l|l|l|l|l|l|l|}
0.07 & 0.26 & 0.08 & 0.02 & 0.02 & 0.03 & 0.02 \\
\hline 0.22 & 0.52 & 0.15 & 0.06 & 0.15 & 0.10 & 0.09 \\
\hline
\end{tabular}

\begin{tabular}{ll|l|l|l|}
\hline 0.38 & 0.20 & 0.07 & 0.0 \\
\hline
\end{tabular}

$0.53 \quad 0.05$

\begin{tabular}{lll}
0.03 & 0.25 \\
\hline
\end{tabular}

\begin{tabular}{l|l|l|l|}
0.39 & 0.07 & 0.75 \\
\hline
\end{tabular}

\begin{tabular}{ll|l|l|l|}
0.54 & 0.12 & 0.55 \\
\hline
\end{tabular}

\begin{tabular}{l|l|l|l|} 
& & 0.07 & 0.26 \\
\hline 0.23 & 0.88 & 0.22 & 0.52 \\
\hline
\end{tabular}

\begin{tabular}{l|l|l|}
\hline 0.08 & 0.02 & 0.15 \\
\hline 0.06
\end{tabular}

\begin{tabular}{|l|l|l|}
\hline 0.15 & 0.16 & 0.09 \\
\hline
\end{tabular}

$\frac{10}{10}$

\begin{tabular}{|l|l|l|l|}
0.15 & 0.04 & 0.02 & 0.0 \\
\hline
\end{tabular}

\begin{tabular}{lll}
0.02 & 0.17 \\
\hline 0.03 & & 0
\end{tabular}

\begin{tabular}{|l|l|l|l|}
\hline 0.15 & 0.05 & 0.17 & 0.09 \\
\hline
\end{tabular}

\begin{tabular}{|l|l|l|}
\hline 0.07 & 0.09 & 0.10 \\
\hline
\end{tabular}

0.12

\begin{tabular}{|l|l|l|l|l|}
\hline 0.15 & 0.14 & 0.04 & 0.05 & 0.04 \\
\hline
\end{tabular}

11

\begin{tabular}{|l|l|l|l|}
\hline 0.15 & 0.02 & 0.15 \\
\hline 1.72 & 0.45 & 1.00 & 0.1
\end{tabular}

0.11

\begin{tabular}{llll}
0.33 & 0.09 \\
\hline & 0.03 & 0.2 & 0.00
\end{tabular}

\begin{tabular}{|l|l|l|}
\hline 0.03 & 0.22 & 0.12 \\
\hline
\end{tabular}

$0.10 \quad 0.05$

0.14

12

\begin{tabular}{|l|l|l|l|l}
\hline 1.71 & 1.40 & 0.85 & 1.0. \\
\hline
\end{tabular}

\begin{tabular}{l|l|l|l}
0.05 & 0.04 & 0. \\
\hline 1.08 & 0.68 & 1. \\
\hline 0.02 & & 0.1
\end{tabular}

\begin{tabular}{|l|l|l|}
\hline 1.72 & 0.45 & 1.00 \\
\hline
\end{tabular}

\begin{tabular}{l|l|l|l|}
0.85 & 0.42 & 0.7
\end{tabular}

\begin{tabular}{l|l|l|l|}
0.10 & 0.25 & 0.20 \\
\hline
\end{tabular}

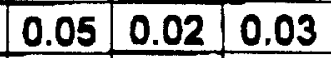

$\frac{13}{14}$

15

16

17

18

10

20

21

22

23

24

25

26

27

28

29

30

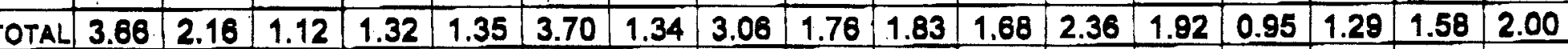
NOTES:

Area 12 Dlp Stick Raln Gape Reading: 3.00 inches $00 / 01 / 88$ thru 07/01/98

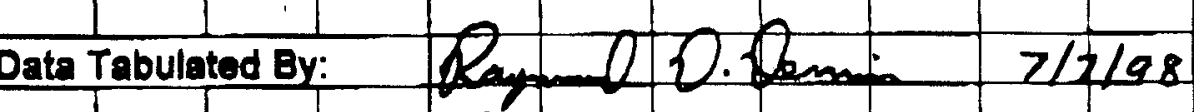

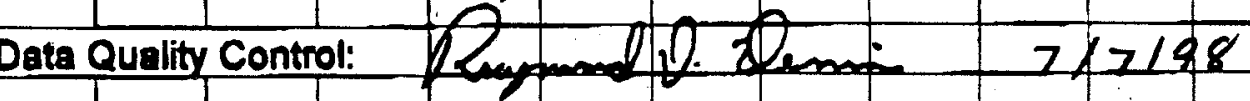

Certifled By:

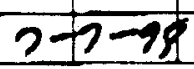




\begin{tabular}{|c|c|c|c|c|c|c|c|c|c|c|c|c|c|c|c|c|c|}
\hline & & & & & & & & NTS & PREC & IPITA & TION & & & & & & \\
\hline & & & & & & & & & July 1 & 888 & & & & & & & \\
\hline & A12 & BJY & CS & DAF & DRA & E Tu & 4JA & $40 \mathrm{Mi}$ & LF2 & MER & $M N$ & PM1 & PHS & RV & TS2 & W5B & UCC \\
\hline 1 & & & & & & & & & & & & & ? & & & & \\
\hline 2 & & & & & & & & & & & & & & & & & \\
\hline 3 & & & & & & & & & & & & & & & & & \\
\hline 4 & & & & & & & & & & & & & & & & & \\
\hline 5 & & & & & & & & & & & & & & & & & \\
\hline 6 & & & & & & & & & & & & & & & & & \\
\hline 7 & & & & & & & & & & & & & & & & & \\
\hline 8 & & & & & & & & & & & & & & & & & \\
\hline 9 & & & & & & & & & & & & & & & & & \\
\hline 10 & & & & & & & & & & & & & & & & & \\
\hline 11 & & & & & & & & . & & & & & & & & & \\
\hline 12 & & & & & & & & & & & & & & & & & \\
\hline 13 & & & & & & & & & & & & & & & & & \\
\hline 14 & & & & & & & & & & & & & & & & & \\
\hline 15 & & & & & & &. & & & & & & & & & & \\
\hline 18 & & & & & & & & & & & & & & & & & \\
\hline 17 & & & & & & & & & & & & & & & & & \\
\hline 18 & & & & & & & & & & & & & & & & & \\
\hline 10 & & & & & & & & & & & & & & & & & \\
\hline 20 & & & & & 0.02 & & & & & 0.02 & & & & & & & \\
\hline 21 & 0.12 & 0.05 & 0.14 & 0.10 & 0.02 & & 0.02 & 0.69 & 0.23 & 0.23 & 0.17 & 0.24 & 0.08 & 0.03 & 0.21 & 0.25 & 0.13 \\
\hline 22 & 0.01 & 0.37 & 0.08 & 0.02 & 0.06 & & 0.03 & 0.01 & 0.02 & 0.02 & 0.01 & 0.02 & 0.20 & & 0.02 & 0.04 & 0.02 \\
\hline 23 & 1.78 & 1.00 & 0.23 & 0.06 & 0.16 & 1.55 & 0.38 & 0.34 & 0.25 & 0.24 & 0.30 & 0.92 & 0.94 & & 0.74 & 0.41 & 0.99 \\
\hline 24 & 0.01 & & & 0.02 & & & & 0.01 & & & & & & & 0.03 & & \\
\hline 25 & & & & & & & & & & & & & & & & & \\
\hline 26 & & & & & & & & & & & & & & & & & \\
\hline 27 & & & 0.02 & & & & 0.12 & 0.02 & & & & & 0.02 & & 0.18 & & \\
\hline 28 & & & & & & & & & & & & & & & & & \\
\hline 29 & & & & & & & & & & & & & & & & & \\
\hline 30 & & & & & & & & & & & & & & & & & \\
\hline 31 & & & & & & & & & & & & & & & & & \\
\hline & & & & & & & & & & & & & & & & & \\
\hline TOTAL & 1.02 & 1.42 & 0.47 & 1.10 & 0.26 & 1.55 & 0.55 & 1.07 & 0.50 & 0.51 & 0.48 & 1.18 & 1.25 & 0.03 & 1.18 & 0.70 & 1.14 \\
\hline & & & & & & & & & & & & & & & & & \\
\hline NOTE & & & & & & & & & & & & & & & & & \\
\hline & & & & & & & & & & & & & & & & & \\
\hline & & & & & & & & & & & & & & & & & \\
\hline Area & 12 Dip & Stick & Rain C & $a g 0 R$ & gading: & & $2.1 \mathrm{lnc}$ & ches & $07101 /$ & 98 thru & $08 / 03$ & & & & & & \\
\hline & & & & & & & & & & & & & & & & & \\
\hline Data & Tabula & $\operatorname{ted} B y$ & & & & & & & $8 / 6$ & 198 & & & & & & & \\
\hline Data & Quallty & Contr & & & & & & & 81 & 6190 & & & & & . & & \\
\hline & & & & & & & & & & & & & & & & & \\
\hline Contifi & $\operatorname{led} B y$ & & & & & & 7 & $a^{\prime}$ & 87 & $2-98$ & & & & & & & \\
\hline
\end{tabular}




\section{NTS PRECIPITATION}

\section{September 1998}

\begin{tabular}{l|l|l|l|l|l|l|l|l|l|l|l|l|l|l|l}
\hline A12 & BJY & CS & DAF & DRA E TU & 4JA & 40 MI & LF2 & MER & MV & PM1 & PHS & RV & TS2 & W5B & UCC \\
\hline
\end{tabular} $\begin{array}{lll}0.02 & 0.02\end{array}$

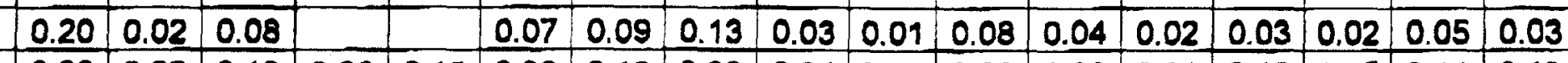

\begin{tabular}{|l|l|l|l|l|l|l|l|l|l|l|l|l|l|l|l|l|l|}
\hline & A12 & BJY & CS & DAF & DRA & E TU & 4JA & 40 MI & LF2 & MER & MV & PM1 & PHS & RV & TS2 & W5B & UCC \\
\hline 1 & & & & & & & & 0.02 & 0.02 & & & & & & 0.02 & & \\
\hline 2 & & & & & & & & & & & & & & & & & \\
\hline 3 & 0.20 & 0.02 & 0.08 & & & 0.07 & 0.09 & 0.13 & 0.03 & 0.01 & 0.08 & 0.04 & 0.02 & 0.03 & 0.02 & 0.05 & 0.03 \\
\hline 4 & 0.68 & 0.22 & 0.10 & 0.20 & 0.15 & 0.33 & 0.16 & 0.20 & 0.64 & 0.16 & 0.20 & 0.38 & 0.31 & 0.18 & 0.25 & 0.14 & 0.13 \\
\hline 5 & 0.77 & 0.02 & 0.40 & 0.05 & & 0.62 & & & 0.10 & & 0.15 & 0.52 & & & 0.04 & & 0.02 \\
\hline 6 & 0.03 & 0.13 & & & 0.03 & 0.03 & 0.02 & & & & & & 0.05 & & & & 2.10 \\
\hline 7 & 0.02 & & & & & & & & & & & 0.04 & & & & 0.04 & 0.02 \\
\hline 8 & 0.18 & 0.04 & 0.24 & 0.08 & & 0.18 & 0.45 & 0.20 & 0.10 & 0.07 & 0.07 & 0.34 & & 0.23 & 0.41 & 0.20 & 0.28 \\
\hline 9 & & & & & & & & & & & & & & & & & 0.02 \\
\hline 10 & & 0.08 & & 0.03 & & & & & & & & & 0.07 & & & 0.01 & \\
\hline 11 & & 0.12 & & 0.07 & & 0.04 & & 0.02 & & & 0.03 & & 0.08 & & & 0.09 & 0.07 \\
\hline 12 & & & & & & & & & & & & & & & & & \\
\hline 13 & & & & & & & & & & & & & & & & & \\
\hline 14 & & & & & & & & & & & & & & & & & \\
\hline 15 & & & & & & & & & & & & & & & & & \\
\hline 16 & & & & & & & & & & & & & & & & & \\
\hline 17 & & & & & & & & & & & & & & & & & \\
\hline 18 & & & & & & & & & & & & & & & & & \\
\hline 19 & & & & & & & & & & & & & & & & & \\
\hline 20 & & & & & & & & & & & & & & & & & \\
\hline 21 & & & & & & & & & & & & & & & & & \\
\hline 22 & & & & & & & & & & & & & & & & & \\
\hline 23 & & & & & & & & & & & & & & & & & \\
\hline 24 & & & & & & & & & & & & & & & & & \\
\hline 25 & & & & & & & & & & & & & & & & & \\
\hline 26 & & & & & & & & & & & & & & & & & \\
\hline 27 & & & & & & & & & & & & & & & & & \\
\hline 28 & & & & & & & & & & & & & & & & & \\
\hline 29 & & & & & & & & & & & & & & & & & \\
\hline 30 & 0.06 & & & & & 0.06 & & & & & 0.01 & & & & & & \\
\hline & & & & & & & & & & & & & & & & & \\
\hline
\end{tabular}

\begin{tabular}{l|l|l|l|l|l|l|l|}
\hline 5 & 0.77 & 0.02 & 0.40 & 0.05 & & 0.62 & \\
\hline 6 & 0.03 & 0.13 & & & 0.03 & 0.03 & 0.02 \\
\hline
\end{tabular}

\begin{tabular}{l|l|}
7 & 0.02 \\
\hline
\end{tabular}

$\frac{7}{8}$
$\frac{9}{10}$
$\frac{11}{12}$
$\frac{13}{14}$
$\frac{15}{15}$

\begin{tabular}{|l|l|l|l|l|l|l}
0.18 & 0.04 & 0.24 & 0.08 \\
\hline
\end{tabular}

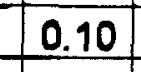

\begin{tabular}{|l|l|l|l|l|l}
0.15 & 0.52 \\
\hline
\end{tabular}

\begin{tabular}{l|l|l|l|l|l|l|l|l|l|l|l|l|l|l|l|l|l}
\hline IOTAL & 1.94 & 0.61 & 0.82 & 0.43 & 0.18 & 1.33 & 0.72 & 0.57 & 0.89 & 0.24 & 0.54 & 1.32 & 0.53 & 0.44 & 0.74 & 0.53 & 2.65 \\
\hline
\end{tabular} NOTES:

Area 12 Dip Stick Rain Gago Reading: $\quad 2.00$ inches $09 / 02 / 98$ thru 10/01/98

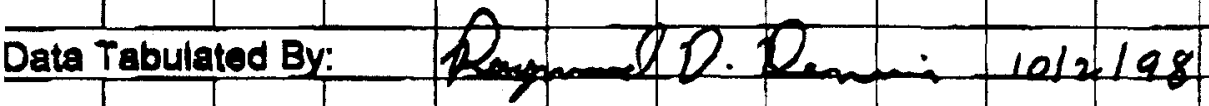

Data Quality Control: Roymmol Dumer cel219K

Certified By:

$10-2-98$ 


\begin{tabular}{|c|c|c|c|c|c|c|c|c|c|c|c|c|c|c|c|c|c|}
\hline & & & & & & & & \multicolumn{4}{|c|}{ NTS PRECIPITATION } & & & & & & \\
\hline & & & & & & & & & & & & & & & & & \\
\hline & & & & & & & & & \multicolumn{3}{|c|}{ October 1898} & & & & & & \\
\hline & & & & & & & & & & & & & & & & & \\
\hline & A12 & BJY & $\mathrm{CS}$ & DAF & DRA & ETu & 4JA & $40 \mathrm{Mi}$ & LF2 & MER & MV & PM1 & PHS & RV & TS2 & W5B & UCC \\
\hline 1 & & & & & & & & & & & & & & & & & \\
\hline 2 & & & & & & & & & & & & & & & & & \\
\hline 3 & & & & & & & & & & & & & & & & & \\
\hline 4 & & & & & & & & & & & & & & & & & \\
\hline 5 & & & & & & & & & & & & & & & & & \\
\hline$B$ & & & & & & & & & & & & & & & & & \\
\hline 7 & & & & & & & & & & & & & & & & & \\
\hline 8 & & & & & & & & & & & & & & & & & \\
\hline 9 & & & & & & & & & & & & & & & & & \\
\hline 10 & & & & & & & & & & & & & & & & & \\
\hline 11 & & & & & & & & & & & & & & & & & \\
\hline 12 & & & & & & & & & & & & & & & & & \\
\hline 13 & & & & & & & & & & & & & & & & & \\
\hline 14 & & & & & & & & & & & & & & & & & \\
\hline 15 & & & & & & & & & & & & & & & & & \\
\hline 16 & & & & & & & & & & & & & & & & & \\
\hline 17 & & & & & & & & & & & & & & & & & \\
\hline 18 & & & & & & & & & & & & & & & & & \\
\hline 19 & & & & & & & & & & & & & & & & & \\
\hline 20 & & & & & & & & & & & & & & & & & \\
\hline 21 & 0.45 & 0.28 & & & & 0.68 & & 0.15 & 0.08 & & 0.03 & 0.54 & 0.16 & & 0.05 & & \\
\hline 22 & & & & & & & & & & & & & & & & & \\
\hline 23 & & & & & & & & & & & & & & & & & \\
\hline 24 & 0.31 & 0.05 & 0.10 & 0.13 & 0.03 & 0.50 & 0.14 & 0.55 & 0.15 & 0.04 & 0.14 & 0.25 & 0.35 & 0.07 & 0.34 & 0.05 & 0.12 \\
\hline 25 & & & & & & & & & & & & & & & & & \\
\hline 26 & 0.05 & 0.02 & & & 0.05 & 0.03 & 0.15 & & 0.01 & 0.04 & 0.02 & & 0.02 & 0.02 & 0.02 & 0.08 & \\
\hline 27 & 0.03 & & & & & 0.05 & & & & & & & & & & & \\
\hline 28 & & & & & & & & & & & & & & & & & \\
\hline $2 \theta$ & 0.22 & 0.23 & & & 0.03 & 0.25 & 0.02 & & & 0.03 & & 0.33 & 0.10 & 0.06 & & 0.02 & 0.02 \\
\hline 30 & 0.02 & & & & & & & & & & & 0.09 & & & & & \\
\hline & & & & & & & & & & & & & & & & & \\
\hline OTAL & 1.08 & 0.59 & 0.10 & 0.13 & 0.11 & 1.49 & 0.31 & 0.70 & 0.24 & 0.11 & 0.19 & 121 & 0.63 & 0.15 & 0.41 & 0.16 & 0.14 \\
\hline & & & & & & & & & & & & & & & & & \\
\hline IOTE! & & & & & & & & & & & & & & & & & \\
\hline & & & & & & & & & & & & & & & & & \\
\hline & & & & & & & & & & & & & & & & & \\
\hline trea 1 & 12 Dip & Stlck & Pain C & age $R$ & eading & & $1.10 \mathrm{ir}$ & ches & $10 / 019$ & 80 thru & $11 / 03 / 8$ & & & & & & \\
\hline & & & & & & & & & & & & & & & & & \\
\hline Deta 1 & Tabula & $\operatorname{tod} B$ & & & & & & & 410 & $4 / 28$ & & & & & & & \\
\hline Jata C & Quality & Cont & & 72 & 0 & 0.8 & & & Wlou & $1 / 98$ & & & & & & & \\
\hline & & & & & & & & & & & & & & & & & \\
\hline intii & $\operatorname{ed~By}$ & & & & & & & 2 & Vhe & E-20 & & & & & & & \\
\hline
\end{tabular}


Post Closure Monitoring Report - CAU No. 91 Section: DISTRIBUTION

Revision: 0

Date: January 25, 1999

\section{DISTRIBUTION LIST}


Bureau of Federal Facilities

Division of Environmental Protection

333 W. Nye Lane, Room 13B

Carson City, NV 89706-0866

Michael McKinnon, Las Vegas Office

Bureau of Federal Facilities

Division of Environmental Protections

555 E. Washington, Suite 4300

Las Vegas, NV 89010

Sabrina Lawrence

Environmental Restoration Division

U.S. Department of Energy, Nevada Operations Office

P.O. Box $98518 \mathrm{M} / \mathrm{S} 505$

Las Vegas, NV 89193-8518

Uncontrolled Copies

Janet Appenzeller-Wing

Environmental Restoration Division

U.S. Department of Energy, Nevada Operations Office

P.O. Box $98518 \mathrm{M} / \mathrm{S} 505$

Las Vegas, NV 89193-8518

Sabine Curtis

Environmental Restoration Division

U.S. Department of Energy, Nevada Operations Office

P.O. Box $98518 \mathrm{M} / \mathrm{S} 505$

Las Vegas, NV 89193-8518

DOE Public Reading Facility

P.O. Box $98521 \mathrm{M} / \mathrm{S}$ NLV040

Las Vegas, NV 89193-8521 
DOE/Nevada Operations Office

Technical Information Resource Center

P.O. Box $98521 \mathrm{M} / \mathrm{S} 505$

Las Vegas, NV 89193-8521

U.S. Department of Energy

Office of Scientific and Technical Information

175 Oak Ridge Turnpike

P.O. Box 62

Oak Ridge, TN 37831-0062

Correspondence Control

Bechtel Nevada

P.O. Box $98521 \mathrm{M} / \mathrm{S}$ NLV008

Las Vegas, NV 89193-8521

Environmental Management Correspondence Control

Bechtel Nevada

P.O. Box $98521 \mathrm{M} / \mathrm{S}$ NLV080

Las Vegas, NV 89193-8521

David Cowser

Bechtel Nevada

P.O. Box $98521 \mathrm{M} / \mathrm{S}$ NLV082

Las Vegas, NV 89193-8521

Anne Heidema

Bechtel Nevada

P.O. Box $98521 \mathrm{M} / \mathrm{S}$ NLV022

Las Vegas, NV 89193-8521

Steve Nacht

Bechtel Nevada

P.O. Box $98521 \mathrm{M} / \mathrm{S}$ NTS306

Las Vegas, NV 89193-8521

Jeff Smith

Bechtel Nevada

P.O. Box $98521 \mathrm{M} / \mathrm{S}$ NTS306

Las Vegas, NV 89193-8521 